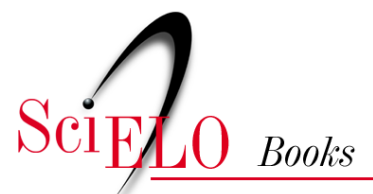

\title{
Viroses emergentes no Brasil
}

\author{
Luiz Jacintho da Silva \\ Rodrigo Nogueira Angerami
}

\section{SciELO Books / SciELO Livros / SciELO Libros}

SILVA, L., and ANGERAMI, RN. Viroses emergentes no Brasil [online]. Rio de Janeiro: Editora FIOCRUZ, 2008, 132 p. Temas em Saúde collection. ISBN 978-85-7541-381-4. https://doi.org/10.7476/9788575413814.

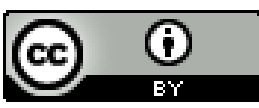

All the contents of this work, except where otherwise noted, is licensed under a Creative Commons Attribution 4.0 International license.

Todo o conteúdo deste trabalho, exceto quando houver ressalva, é publicado sob a licença Creative Commons Atribição 4.0. 
Viroses Emergentes no Brasil 


\section{FUNDAÇÃO OSWALDO CRUZ}

Presidente

Paulo Marchiori Buss

Vice-Presidente de Ensino, Informação e Comunicação

Maria do Carmo Leal

\section{EDITORA FIOCRUZ}

Diretora

Maria do Carmo Leal

Editor Executivo

João Carlos Canossa Mendes

Editores Científicos

Nísia Trindade Lima

Ricardo Ventura Santos

Conselho Editorial

Carlos E. A. Coimbra Jr.

Gerson Oliveira Penna

Gilberto Hochman

Ligia Vieira da Silva

Maria Cecília de Souza Minayo

Maria Elizabeth Lopes Moreira

Pedro Lagerblad de Oliveira

Ricardo Lourenço de Oliveira

Coleção Temas em Saúde

Editores Responsáveis

Maria do Carmo Leal

Nísia Trindade Lima

Ricardo Ventura Santos 


\author{
LUIZ JACINTHO DA SILVA \\ RODRIGO NOGUEIRA ANGERAMI
}

\title{
Viroses Emergentes no Brasil
}

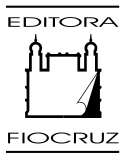


Copyright (C) 2008 dos autores

Todos os direitos desta edição reservados à

FUNDAÇ̃̃O OSWALDO CRUZ / EDITORA

ISBN: 978-85-7541-156-8

Capa, projeto gráfico e editoração

Carlota Rios

Revisão

Ana Lúcia Prôa

Apoio na revisão de provas

Gislene Monteiro

Supervisão editorial

M. Cecilia Gomes Barbosa Moreira

Catalogação na fonte

Centro de Informação Científica e Tecnológica

Biblioteca da Escola Nacional de Saúde Pública Sergio Arouca

S586v Silva, Luiz Jacintho da

Viroses Emergentes no Brasil. / Luiz Jacintho da Silva e Rodrigo Nogueira Angerami. - Rio de Janeiro: Editora FIOCRUZ, 2008.

136 p. (Coleção Temas em Saúde)

1. Viroses - história. 2. Viroses - epidemiologia. 3. Doenças Transmissíveis Emergentes - história.

4. Doenças Transmissíveis Emergentes - epidemiologia. 5. Febre Amarela. 6. Dengue. 7. Aedes. 8. Síndrome de Imunodeficiência Adquirida. I. Angerami, Rodrigo Nogueira. II.Título.

CDD - 22.ed. - 616.920981

2008

EDITORA FIOCRUZ

Av. Brasil, 4036 - Térreo - sala 112 - Manguinhos

21040-361 - Rio de Janeiro - RJ

Tels.: (21) 3882-9039 / 3882-9041

Telefax: (21) 3882-9006

e-mail: editora@fiocruz.br

http://www.fiocruz.br 


\section{SUMÁRIO}

Apresentação

1. A Importância das Viroses Emergentes

2. Emergência de Viroses e seus Determinantes

3. Um Pouco sobre História e as Viroses Emergentes 29

4. Arboviroses no Brasil Contemporâneo

5. Mais Viroses Emergentes

6. Vírus, Especulações e Perspectivas

O Futuro a Curto, Médio e Longo Prazos

Referências

Sugestões de Leituras

Glossário 


\section{Apresentação}

\section{Tempora mutantur, nos et mutamur in illis. (Os tempos mudam e nós mudamos com eles.) John Owen, Epigrammata, 1615}

O famoso dito popular "nada como um dia após o outro" nos lembra que as coisas mudam e nós com elas. Para entender o que são e o que representam as viroses emergentes no Brasil, é necessário entender que as doenças infecciosas, entre tantas outras coisas, são extremamente dinâmicas: o contexto de ontem difere do de hoje, o de amanhã será diferente também, ainda que exista entre eles um nexo de causalidade, muitas vezes sutil.

Costuma-se ler e ouvir que a saúde pública regrediu no Brasil com a volta de doenças eliminadas no passado. Ainda que uma análise superficial e rápida leve a esta conclusão, pretendemos mostrar que a ocorrência e distribuição das doenças virais é um processo evolutivo, com características peculiares a cada época e lugar. Não existe volta. As doenças virais são como as águas de um rio.

A febre amarela de Oswaldo Cruz não era como a febre amarela de hoje. Mais importante, os métodos empregados por Emílio Ribas e Oswaldo Cruz no combate ao Aedes aegypti seriam hoje tão arcaicos, inadequados e ineficazes quanto as penas e os tinteiros então utilizados para registrar a ocorrência de casos. 
Uma das primeiras tarefas que foi designada há mais de trinta anos para um dos autores deste livro (Luiz Jacintho da Silva), quando ainda aspirante a professor universitário, foi a de dar uma aula sobre dengue e outras arboviroses a uma turma de desinteressados alunos de medicina. "Dengue?", questionavam eles. Uma doença que não existe no Brasil! Além da dengue, não existiam a Aids e muitas das viroses discutidas neste livro.

Ao longo desse tempo, doenças foram e vieram, algumas poucas - vieram e, aparentemente, foram, como a síndrome respiratória aguda grave. As viroses emergentes, particularmente a Aids, transformaram a prática médica, a saúde pública e a própria sociedade. Conceitos mudaram: sexo seguro era aquele feito com a porta e as janelas fechadas, sem risco de interrupção; luvas de látex, na prática médica, eram quase sempre para não contaminar o paciente, quase nunca para proteger o profissional.

As doenças servem para evidenciar a fragilidade da vida, geralmente mudam modos de pensar individuais. Nas sociedades, as doenças também evidenciam as fragilidades e levam a mudanças. A epidemia de peste bubônica teve um significativo impacto na história da Europa medieval, assim como a varíola e outras doenças varreram da história civilizações que existiam nas Américas antes da chegada dos europeus.

O livro está estruturado em seis capítulos, no qual cobrimos temas como a importância das viroses emergentes, o conceito de emergência e seus determinantes, aspectos históricos dessas viroses, exemplos de importantes viroses emergentes no Brasil contemporâneo, além de perspectivas futuras sobre o tema. Já que utilizamos uma grande quantidade de termos técnicos, optamos pela inclusão de um glossário no final do livro. 
Esperamos que facilite a leitura, principalmente para aqueles não tão familiarizados com o assunto.

O convite da Editora Fiocruz para publicar este livro foi recebido como uma honraria. Felizmente os editores científicos nos relembraram continuamente quanto à importância do tema das viroses emergentes, o que nos estimulou a escrever o texto. 



\section{I A Importância das Viroses EMERGENTES}

D as 57 milhões de mortes ocorridas anualmente em todo o mundo, cerca de 15 milhões, mais de $25 \%$, se devem a doenças infecciosas, sem contar aquelas que são conseqüência de infecções adquiridas anos antes, como a doença cardíaca causada pela infecção pelo estreptococo do grupo A, a cirrose hepática e o hepatocarcinoma secundários à infecção pelos vírus das hepatites B e C, o câncer do colo uterino causado pela infecção pelo papilomavírus humano e as infecções hospitalares.

Apesar de todo o progresso da medicina e da saúde pública, as doenças infecciosas ainda determinam um significativo impacto negativo na saúde humana e, infelizmente, são as crianças que pagam o maior tributo, com aproximadamente três milhões morrendo anualmente somente de malária e doenças diarréicas.

Determinar exatamente quanto desses óbitos são devidos a infecções virais é quase um exercício de adivinhação. Muitas doenças virais são de difícil identificação e, como a maior parte dessas mortes se dá em regiões do mundo com sistemas de saúde precários ou mesmo ausentes, sobra apenas o recurso de estimativas grosseiras. Basta lembrar algumas doenças virais, como a Aids, a dengue, a diarréia por rotavírus e a hepatite B, para constatar que o impacto delas em saúde pública é considerável. Adiante comentaremos um pouco a dinâmica dessas doenças, a maioria das quais em franca expansão, seja geográfica, seja em número de casos. 
Veremos, também, que a ocorrência de surtos e epidemias de doenças virais anteriormente desconhecidas ou de pequena importância não é fenômeno recente. A varíola, introduzida na América pelos europeus a partir do século XVI, teria virtualmente exterminado populações inteiras, estimando-se que, somente no México, de 10 a 15 milhões de astecas morreram de varíola em 1520 e 1521. Em 1918, cerca de 50 milhões de pessoas teriam morrido em todo o mundo durante a pandemia de gripe. A Aids já causou a morte de mais de 60 milhões de pessoas desde seu surgimento no início da década de 1980, a maioria das quais na África subsaariana.

Conhecer essas doenças e seus determinantes é etapa fundamental para alcançar o seu controle. Para isso, é importante entender que não existe explicação simples. As doenças infecciosas em geral, as virais incluídas, são processos complexos, em que um grande número de fatores interage determinando sua disseminação.

Importante lembrar que as infecções emergentes, virais ou não, não são um problema apenas para humanos. Doenças infecciosas emergentes têm sido detectadas em animais, domesticados ou silvestres, e em plantas. As doenças infecciosas de animais e de plantas determinam problemas econômicos significativos e, no caso dos animais, muitas vezes representam um risco para a saúde humana.

Uma revisão das viroses emergentes de animais e de plantas não é o nosso propósito, mas é importante que se entenda que os determinantes dessas viroses são semelhantes, muitas vezes idênticos, aos das viroses emergentes em humanos.

Os vírus de plantas não representam risco a humanos e animais, com exceção das implicações econômicas e da disponibilidade 
de alimentos. Como exemplos de viroses de plantas, podemos citar a 'tristeza' da laranjeira, surgida na década de 1940 e que devastou a citricultura paulista e desapareceu apenas depois da introdução de variantes resistentes, e mais recentemente o vírus da morte súbita da laranjeira, aparentemente uma variante do vírus da tristeza. Já a virose de animais que ganhou mais destaque nos últimos anos é, sem dúvida, a influenza (ver adiante), uma doença de aves silvestres.

\section{Conceitos de vírus e de virose emergente}

Ainda que o comportamento epidemiológico das doenças infecciosas tenha sido sempre o de emergência e desaparecimento, foi após a Segunda Guerra Mundial - e, de maneira mais evidente, a partir de meados da década de 1970 - que o fenômeno 'doenças emergentes' passou a se constituir em objeto de preocupação. A esteira da Segunda Guerra trouxe uma série de transformações políticas, econômicas e sociais em boa parte do mundo, mais intensamente nas antigas colônias européias da Ásia, África e Oceania.

Urbanização, crescimento demográfico, alteração de fronteiras e formação de blocos geopolíticos tiveram como conseqüência grandes obras com impacto não somente sobre o ecossistema - como rodovias, represas e sistemas de irrigação mas também sobre os padrões de ocorrência e distribuição das doenças infecciosas.

Foi por volta de 1976 que ocorreram o reconhecimento da doença dos legionários nos Estados Unidos, o primeiro surto de infecção pelo vírus Ebola na República Democrática do Congo (antigo Zaire) e a ameaça de uma nova pandemia de influenza, com a identificação de infecção humana com o vírus 
da influenza suína. Com isso, ficou patente a constante transformação do cenário epidemiológico das doenças infecciosas, que trazia um novo desafio a cada curva da estrada.

A pandemia de Aids, evidenciada alguns anos após, foi o golpe de misericórdia na presunção dos que imaginavam que as doenças infecciosas deixariam de ser um problema de saúde pública à medida que se verificasse o desenvolvimento econômico e social. Desde então, o problema das doenças infecciosas, particularmente as emergentes, passou a integrar a agenda dos serviços e organizações de saúde pública em todo o mundo. Como enfrentar o problema é objeto de muita discussão.

\section{VÍRUS E VIROSES}

Vírus constituem a menor entidade biológica capaz de se replicar, ainda que necessitem sempre de uma célula, animal ou vegetal, para essa replicação. São partículas constituídas de proteínas e acido nucléico - podendo, as maiores, conter lípides - e de vida intracelular obrigatória. Reproduzem-se pela invasão e posse do controle da maquinaria de auto-reprodução celular. O termo 'vírus' geralmente refere-se às partículas que infectam eucariontes (organismos cujas células têm carioteca, como plantas ou animais), enquanto os termos 'bacteriófago' ou 'fago' são utilizados para descrever aqueles que infectam procariontes (domínios bactéria e archaea).

Tipicamente, estas partículas carregam uma pequena quantidade de ácido nucléico (seja DNA ou RNA, ou ambos), cercada por alguma estrutura protetora consistente de proteína - também conhecida como 'envelope protéico' ou 'cápsula protéica' - ou constituída de proteína e lipídio. Das 1.739 .600 espécies de seres vivos existentes, os vírus representam 3.600 delas. 
Quando a existência dos vírus foi demonstrada, a maneira de fazê-lo se dava por meio da filtragem do material, a fim de reter organismos como bactérias e fungos, seguida da inoculação desse material filtrado em animais de laboratório, buscando reproduzir a doença.

Até meados do século XX, o único processo para isolar e manter os vírus em laboratório era através da inoculação em animais ou em ovos embrionados, o que dificultava muito o seu estudo.

Com o advento do microscópio eletrônico e do cultivo de células e tecidos em meio artificial, o conhecimento acerca dos vírus sofreu um salto qualitativo, crescendo o número de doenças com etiologia viral demonstrada.

O desenvolvimento de métodos de detecção de material genético (DNA ou RNA) permite a identificação de vírus sem a necessidade do seu isolamento em animais ou em cultivo celular. Muitos vírus anteriormente desconhecidos, por não se desenvolverem em cultivo celular ou animais de laboratório, puderam ser associados a doenças. O mais relevante exemplo é o do vírus da hepatite $C$, não cultivável, mas identificado em tecidos humanos.

Até época recente, os vírus eram classificados por suas características morfológicas, bioquímicas e antigênicas, e catalogados num sistema idêntico ao utilizado para outros seres vivos. Essa sistemática, no entanto, deixava muito a desejar. Foi somente com o advento da biologia molecular que os vírus passaram a ser estudados através do seu genoma.

Apesar de ainda se manter a classificação em ordens, famílias e gêneros, a tendência é utilizar cada vez mais a classificação por características genéticas, em grupos e clades. Atualmente, os vírus recebem seu nome segundo o local onde foram identificados 
pela primeira vez (Ebola, Marburg, Nilo Ocidental, por exemplo). Antes, não havia norma, podendo ser denominados segundo a doença que causavam (vírus da dengue, por exemplo), seu aspecto à micrografia eletrônica (arenavírus) ou receber o nome do pesquisador que o identificou (vírus de Epstein-Barr, por exemplo).

\section{Conceito de doença infecciosa emergente}

Ainda que existam na literatura inúmeras definições de doenças emergentes - todas elas, no fundo, variações de uma única -, é melhor entendê-las como um conceito mais abrangente e não como uma definição precisa. Este conceito compreende um conjunto amplo de doenças infecciosas que, nos últimos vinte a trinta anos, apresentaram pelo menos um dos comportamentos a seguir:

- doenças que inexistiam na espécie humana, mas que passaram a ocorrer, muitas vezes constituindo um sério problema de saúde pública, como Aids, febre de Lassa e Ebola;

- doenças muitas vezes em declínio, controladas ou aparentemente erradicadas, que voltam a ocorrer com novas características biológicas e epidemiológicas, como tuberculose, cólera e dengue;

- doenças anteriormente não reconhecidas, mas muito provavelmente já existentes, como infecções por hantavírus, hepatite $\mathrm{C}$ e legionelose;

- doenças que ressurgem após um efetivo controle, como a peste e o sarampo.

Estes comportamentos são superponíveis e, muitas vezes, difíceis de serem definidos com exatidão. O importante é enfatizar 
que as doenças infecciosas emergentes constituem um conjunto de doenças que se tornam, pelos mais diferentes motivos, um problema de saúde pública.

\section{As VIROSES EMERGENTES}

Ainda que as doenças infecciosas emergentes possam ser determinadas por qualquer tipo de microrganismo, as viroses merecem uma atenção diferenciada, não só pelo seu maior número e diversidade, mas também pela propriedade de muitos vírus sofrerem mutações e, portanto, gerarem mudanças de comportamento numa intensidade e velocidade maiores do que bactérias, protozoários ou fungos.

Nas últimas décadas, diversas doenças virais anteriormente desconhecidas foram descritas. A mais notável delas, sem dúvida, é a Aids. Tal como a Aids, praticamente todas as novas viroses descritas são RNA vírus, principalmente das familias Arenaviridae, Hantaviridae, Retroviridae e Filoviridae. Os RNA vírus são mais susceptíveis a mutações e, portanto, à adaptação a novos hospedeiros ou vetores. O quadro clínico mais freqüente dessas viroses é o das febres hemorrágicas, muitas delas com elevada letalidade, como a febre hemorrágica de Ebola e a febre de Lassa, ambas de origem africana. Nas Américas, os hantavírus, determinando uma síndrome respiratória, foram identificados nos Estados Unidos no início da década de 1990, sendo posteriormente reconhecidos em quase toda a América, inclusive no Brasil.

As últimas décadas assistiram ao surgimento de novos vírus e doenças infecciosas virais em número crescente, como vemos nos Quadros 1 a 3. 
Quadro 1 - Vírus identificados de 1972 a 1989

\begin{tabular}{|l|}
\hline Calicivírus \\
\hline Astrovírus \\
\hline Ebola \\
\hline Hantavírus \\
\hline HCV \\
\hline HHV-6 \\
\hline HIV $1 / 2$ \\
\hline HTLV I e HTLV II \\
\hline Parvovírus B19 \\
\hline Rotavírus \\
\hline
\end{tabular}

Quadro 2 - Vírus identificados de 1990 a 1999

\begin{tabular}{|l|}
\hline HHV-7 \\
\hline Enterovírus 71 \\
\hline Hantavírus americanos \\
\hline Hendra \\
\hline HEV \\
\hline HFV \\
\hline HGV \\
\hline HHV-8 (KSHV) \\
\hline Influenza A H5N1 e H9N1 \\
\hline Nipah \\
\hline Sabiá \\
\hline TTV \\
\hline
\end{tabular}


Quadro 3 - Vírus identificados de 1999 a 2006

\begin{tabular}{|l|}
\hline Coronavírus humano (síndrome respiratória aguda grave) \\
\hline Metapneumovírus humano \\
\hline Bocavírus \\
\hline
\end{tabular}

Muitos desses vírus representam doenças efetivamente novas, surgidas recentemente, como a Aids ou a febre hemorrágica de Ebola. Outros, como o vírus da hepatite $\mathrm{C}$ e os rotavírus, são agentes de doenças conhecidas há muito tempo, mas cuja etiologia, ainda que muitas vezes intuída como viral, não havia sido identificada, dificultando a caracterização da doença e, por conseqüência, seu controle e tratamento. Outras viroses consideradas emergentes, como a febre do Nilo Ocidental, são conhecidas há várias décadas, porém só recentemente se transformaram em problemas de saúde pública de âmbito mundial, deixando de ser doenças de importância restrita a pequenas áreas ou regiões esparsamente habitadas.

A maioria das viroses emergentes são zoonoses causadas por vírus RNA, ainda que existam exceções. Alterações do comportamento humano possibilitando a infecção humana são os determinantes mais freqüentes para a emergência de novas viroses, muito mais do que a simples alteração genética do vírus. $O$ processo de adaptação do vírus zoonótico aos humanos é muitas vezes prolongado, como parece ter ocorrido com o vírus da imunodeficiência humana (HIV), ou aparentemente imediato, como no caso do coronavírus humano, agente etiológico da síndrome respiratória aguda grave (que será vista em detalhes no capítulo 2), ou dos vírus Nipah e Hendra, essas três viroses inexistentes no Brasil. 
Primatas, roedores e artrópodes comumente estão envolvidos. Primatas, no caso do HIV e da febre amarela; roedores, no caso dos hantavírus e dos arenavírus; e artrópodes, no caso da dengue e da febre do Nilo Ocidental e muitas outras. 


\section{I Emergência de Viroses e seus
Determinantes}

Entendemos que é importante repetir um conceito básico para a compreensão do processo de 'emergência' ou 'surgimento' de uma infecção viral. Vírus são simples, constituídos de pouco mais do que material genético encapsulado em proteína. Contêm, portanto, apenas o essencial para serem considerados seres vivos. Ao contrário dos seres biológicos mais complexos, como determinados animais e plantas, em que a reprodução implica a troca sistemática de material genético entre diferentes indivíduos, contando com mecanismos bioquímicos para reparar erros na transcrição desse material, a reprodução dos vírus prescinde de outros indivíduos. Eles são auto-replicáveis, fazendo uso da estrutura de uma célula, seja bacteriana, de animal ou de planta. Eventuais erros na transcrição do material genético são compensados pelo imenso número de indivíduos resultantes da reprodução de um único vírus. A enorme quantidade de indivíduos resultantes, a velocidade do processo de replicação e a inadequação de mecanismos de controle da transcrição do material genético acarretam um elevado número de mutações, o que por si só explicaria o surgimento, em determinados intervalos, de vírus com características diferentes dos seus ancestrais.

À medida que a ciência conhece melhor a intimidade desse processo de replicação, fica evidente que esse é um importante 
determinante do processo de emergência de novas viroses. Do surgimento de uma variante de vírus à ocorrência de uma epidemia, vai uma grande distância. Ainda que explicações sejam sempre buscadas para a ocorrência desta ou daquela epidemia, a verdade é que, na imensa maioria das vezes, com a exceção eventual de pequenos surtos localizados, a disseminação de uma doença viral é o resultado de um conjunto de fatores agindo em sinergia. A facilidade crescente com que os fatores ligados ao vírus são demonstrados conduz à interpretação errônea de que estes seriam os mais importantes. Podem até ser, mas nem sempre.

É fato notório que populações isoladas raramente são palco de epidemias, a não ser quando entram em contato com outros grupos. Pequenas populações não são capazes de sustentar a transmissão de vírus, com raras exceções. Doenças epidêmicas, como a varíola e o sarampo, com certeza surgiram apenas quando os humanos deixaram de lado pequenos bandos nômades para viver em grupamentos maiores e sedentários. A evolução da espécie humana trouxe também a domesticação de animais, o que teria permitido o 'salto de espécies', a adaptação de microrganismos animais aos humanos. $\mathrm{O}$ vírus do sarampo teria se derivado do vírus da cinomose canina ou do vírus da Rinderpest, ou pelo menos teve um ancestral comum. A varíola seria uma derivação de um dos muitos vírus da varíola que acomete animais domesticados, como os camelos e os bovinos.

Essa passagem e adaptação dos vírus para a espécie humana não poderia levar à ocorrência de uma doença epidêmica se não se verificassem mudanças na sociedade que viabilizassem isso. A febre amarela e a dengue, por exemplo, jamais seriam doenças epidêmicas se não fossem o surgimento de cidades e a adaptação de um vetor artrópode ao meio urbano. Populações nômades 
que vivem em áreas silvestres podem ter febre amarela, mas essa não se transmitirá entre humanos.

A emergência das doenças infecciosas se dá, portanto, desde que humanos passaram a viver em sociedade e ocorreu a interação entre grupos. A maneira como as sociedades se relacionam com a natureza é um determinante crítico no processo de emergência. $\mathrm{O}$ que se verifica hoje, no entanto, é a intensificação de um processo milenar. A mudança é quantitativa, não qualitativa. As sociedades estão a cada dia maiores, interagindo cada vez mais e mais rapidamente. A interação com a natureza é mais intensa e extensa.

Entender esses processos e buscar a correlação deles com a circulação dos vírus ainda não permite estabelecer causalidade na maioria das vezes e muito menos fazer previsões. A análise da situação epidemiológica é, de certa maneira, semelhante à análise da economia e, tal como essa, permite apenas previsões de tendência com um certo grau de imprecisão, mas suficientemente confiáveis para antecipar alguns eventos.

Se existe, porém, uma explicação básica para a emergência de doenças virais e para o 'salto de espécies', esta deve ser buscada na relação das sociedades humanas com a natureza. As perturbações ecológicas quase sempre estão na raiz dos processos que resultam na emergência de doenças virais. Essas perturbações, muitas delas ocorridas há milênios, vão desde a domesticação de espécies animais até o desmatamento, que reduz o babitat natural de diferentes espécies animais, forçando-as a um convívio mais próximo com humanos. 


\section{SíndROME RESPIRATÓRIA AGUDA GRAVE:}

\section{0 'ensaio geral' de UMa VIROSE PANDÊmica}

A pandemia, ainda que de proporções reduzidas, da síndrome respiratória aguda grave (SRAG ou, como é mais conhecida, SARS, do inglês Severe Acute Respiratory Syndrome) foi a transformação em dura realidade do muito que se tem falado, escrito e discutido sobre doenças infecciosas emergentes. Em novembro de 2002, um surto de doença respiratória irrompeu em Guangdong, província chinesa situada no sudoeste do país. A princípio interpretada como um surto de pneumonia atípica - foi isolada a Chlamydia pneumoniae em quatro pacientes -, as autoridades chinesas não parecem ter atribuído maior importância ao surto até três meses depois, em fevereiro de 2003, quando casos foram identificados em Hong Kong, região vizinha, e em Hanói, no Vietnã, não muito distante de Guangdong. Nesses dois locais, e logo depois em Cingapura e em Toronto, Canadá, ficou evidente a elevada transmissibilidade da síndrome no ambiente hospitalar, onde houve a ocorrência de casos secundários e óbitos entre pessoal hospitalar, o que levou à interdição de hospitais em Cingapura, Toronto e Hong Kong.

$\mathrm{O}$ mundo rapidamente percebeu que estava diante de uma doença respiratória de etiologia ainda não esclarecida. A preocupação causada por essa síndrome foi tão grande que a Organização Mundial da Saúde (OMS) emitiu um alerta de âmbito mundial e, pela primeira vez em sua história, recomendou que se evitasse viajar para as áreas afetadas: Guangdong e Hong Kong.

Tão rapidamente quanto a doença atingiu diferentes pontos do planeta, sua etiologia foi demonstrada no tempo recorde de cerca de um mês. Trata-se de um coronavírus até então não 
isolado, nem em humanos nem em animais. Vírus da família Coronaviridae são RNA vírus de filamento único e senso positivo e não são causa de doença grave em humanos.

Eram conhecidos dois diferentes coronavírus humanos (229E e OC49), ambos causam um resfriado comum, podendo, eventualmente, provocar doença respiratória baixa. Epidemias causadas por coronavírus são desconhecidas, mas surtos de doença respiratória baixa, semelhantes até certo ponto à atual pandemia, não são totalmente desconhecidos. Diferentes coronavírus provocam diversas doenças em animais, como a peritonite infecciosa felina, a primeira das doenças causadas por coronavírus a ser descrita já em 1912. Foi apenas em 1937 que o primeiro coronavírus foi isolado, de galinhas, e somente em meados da década de 1960 é que seu papel em doença humana foi reconhecido.

Apesar de não ter seu RNA segmentado como os vírus da influenza, os coronavírus são sujeitos a freqüentes recombinações, razão pela qual o surgimento de um novo coronavírus não é causa para espanto. Aliás, os coronavírus há muito vêm sendo usados como modelo para a investigação de mutações que permitem o salto de espécie.

Já foi demonstrado que infecção persistente pelo vírus da hepatite murina acaba determinando o surgimento de variantes capazes de infectar outras espécies. O fenômeno não é desconhecido. Pelo contrário, ocorre com freqüência com o vírus da influenza $\mathrm{A}$, aconteceu em algum momento com o vírus da imunodeficiência humana e com outros RNA vírus, como o Nipah e o Hendra, ambos morbilivírus.

O que assustou na pandemia da SARS não foi tanto o número de casos ou sua letalidade, já que foram pouco mais de oito mil 
casos e oitocentos óbitos. Num período igual, uma pandemia de influenza, causada por uma variante nova, teria determinado milhões de casos. O que assusta é a concretização de inúmeras previsões sobre doenças emergentes.

Doenças infecciosas emergentes não são fruto de mentes paranóicas. Vêm ocorrendo há milhares de anos: peste bubônica, cólera Eltor, gripe espanhola, Aids... Isso para citar apenas algumas. A preocupação maior é a constatação da velocidade de sua disseminação. Em 1894, teve início em Hong Kong a terceira pandemia de peste bubônica e foram necessários cinco anos para que chegasse ao Brasil. Desta vez, bastaram alguns dias para o aparecimento dos primeiros casos suspeitos. Determinantes sempre lembrados como decisivos para a ocorrência de doenças emergentes - a grande densidade populacional e a velocidade dos transportes - estiveram presentes.

Há o reverso da medalha. Esta já foi considerada a primeira pandemia do século XXI. Talvez. Mas, com certeza, foi a primeira pandemia da era da Internet. Somente pela disponibilidade da rede mundial de computadores tem sido possível acompanhar de perto a evolução da pandemia, seguir as recomendações internacionais e compartilhar informações, o que já permitiu a elaboração de uma reação em cadeia da polimerase para a detecção do novo vírus. Foi pelo fácil e rápido acesso às informações que os serviços de saúde do mundo afora puderam se preparar para a eventual chegada de pacientes, minimizando o impacto e impedindo a transmissão da SARS. Pelo menos duas tradicionais revistas médicas se apressaram a colocar à disposição, sem custo, os primeiros estudos sobre a SARS. Ela deve ser considerada, sim, a primeira pandemia pós-moderna, a primeira pandemia de uma sociedade globalizada e baseada na 
informação. Marx já dizia que os problemas somente ocorrem quando estamos preparados para alcançar sua solução. Não fosse o domínio da biologia molecular e da informática, aí sim teríamos uma pandemia de impacto muito maior e pior.

A SARS veio mostrar a quantos queiram e possam ver que a doença está globalizada, porém está claro que a saúde ainda não. É necessário urgentemente adequar a saúde pública à era pósmoderna. Não se trata de uma fantasia ou de um sonho de uma noite de verão. As doenças mudaram... Cabe adaptar a saúde pública e globalizar também a saúde. 



\section{I Um Pouco SOBRe História e AS VirOSES EMERGENTES}

Pouquíssimas doenças virais de impacto na saúde pública brasileira são originárias do continente americano. Ainda que não seja possível demonstrar que algumas dessas doenças não existiam aqui antes da chegada dos europeus, em muitos casos há suficiente evidência de que foram importadas em algum momento de nossa história.

A 'descoberta' e a ocupação da América pelos europeus teve um impacto ecológico significativo, muitas vezes desconsiderado pelos historiadores. Plantas e animais foram mutuamente introduzidos, agentes infecciosos também. Porém, a quantidade de agentes infecciosos introduzidos na América a partir da Europa e África supera em muito a dos que foram levados da América. Nesta última categoria, encontra-se, ainda assim sem um consenso, a sífilis.

No tocante às doenças virais, praticamente todas com impacto significativo em saúde pública na atualidade foram introduzidas em algum momento da nossa história. A ausência de relatos escritos contribui para o nosso desconhecimento do contexto epidemiológico das Américas antes da chegada dos europeus.

\section{PERÍODO COLONIAL}

Os primeiros relatos dos colonizadores portugueses sobre o Brasil já mencionam surtos de varíola nos primeiros assentamentos, com repercussão sobre a população autóctone, 
que, a exemplo do que ocorreu na América de ocupação espanhola, foi significativamente reduzida por sucessivos surtos de varíola e, com quase toda a certeza, de sarampo e influenza. Com respeito a esta última, ainda que não existam relatos precisos sobre a sua ocorrência no período colonial, há registro do que teria sido a primeira pandemia de influenza em 1580, sabidamente afetando a América.

Depois da varíola, sem dúvida a febre amarela foi a doença viral de maior impacto tanto na saúde pública como na opinião pública. Introduzida na América pelo tráfico de escravos africanos, a febre amarela e o seu vetor, o mosquito $A$. aegypti, teriam chegado inicialmente ao Caribe, afetando as então colônias européias assim como o sul dos Estados Unidos, particularmente a região da Louisiana, sucessivamente possessão espanhola, francesa e depois norte-americana, possivelmente já no século XVI.

Ao longo dos séculos XVII, XVIII, XIX até o início do século $\mathrm{XX}$, epidemias de febre amarela ocorreram na América, particularmente na costa Atlântica e no Caribe, de Boston a Buenos Aires, mas também na costa do Pacífico, do Peru ao México.

\section{IMPÉRIO}

Foi durante o período imperial que as maiores epidemias de febre amarela foram registradas no Brasil, a mais importante delas a de 1850, no Rio de Janeiro. Essa epidemia marca um aparente reinício dos surtos de febre amarela no Brasil, aparentemente ausentes ou não percebidos ao longo do século XVIII e da primeira metade do século XIX, como se depreende do artigo de um médico estrangeiro no Brasil: "até recentemente [o Brasil] vinha sendo considerado como inteiramente isento de doenças epidêmicas graves de qualquer natureza" (William, 1851: 450). 
Essa epidemia causou um significativo impacto na opinião pública e oficial, como se vê pelo conteúdo do Aviso de n. 10, do Ministério do Império, de 14 de fevereiro de 1850, com 33 parágrafos, dos quais destaco alguns (Chalhoub, 1999):

$\int 16$ - São inteiramente proibidos os dobres de sinos.

$\llbracket 20$ - Os mendigos serão recolhidos aos lugares que lhes forem destinados e obrigados a lavarem-se e a mudar de roupa, que para esse fim lhes será fornecida.

\24 - Serão quanto antes entupidas e completamente aterradas todas as valas e canos de esgoto que não forem muito precisos, cuidando-se na limpeza dos indispensáveis, e fazendo-os lavar com grandes e repetidas correntes de água limpa.

Havia o temor de que ocorresse no Brasil algo semelhante ao que acontecera alguns anos antes no Haiti, onde sucessivas epidemias de febre amarela reduziram e enfraqueceram a população branca de colonizadores franceses e permitiram a revolta dos escravos, que levou à independência do Haiti. Não podemos esquecer que, em meados do século XIX, no Rio de Janeiro, a população escrava superava a de pessoas livres.

A varíola continuava grassando no país, apesar da vacinação introduzida no Brasil em 1804. Esta nunca foi regular e sistemática, tendo, aparentemente, pouco impacto na disseminação da doença.

Também presente já nesse período, mas sem causar grande impacto, estava a dengue. Há pelo menos um relato sugerindo o fato. Importante salientar que a dengue causou grandes epidemias na região do Caribe e nos Estados Unidos até o início do século 
$\mathrm{XX}$, e o $A$. aegypti, vetor da doença, era encontrado em grande quantidade nas cidades brasileiras.

\section{A REPÚBLica VELHA E A REPÚBLICA NOVA}

No verão anterior ao da proclamação da República, irrompeu no Rio de Janeiro uma grande epidemia de febre amarela, que se disseminou por várias regiões do centro-sul brasileiro, particularmente pelo interior do estado de São Paulo. Ao lado da febre amarela, a varíola continuava como uma doença endêmico-epidêmica no Brasil. Além dessas duas viroses, existe relato de que a influenza ocorria no país.

Com o estabelecimento dos institutos de pesquisa em saúde pública no Brasil, notadamente em São Paulo - Instituto Bacteriológico, hoje Adolfo Lutz, e Instituto Butantan - e no Rio de Janeiro - Manguinhos, hoje Fundação Oswaldo Cruz (Fiocruz) -, as doenças infecciosas de interesse da saúde pública passaram a ser estudadas.

Esse foi um período de otimismo na área da saúde pública, não somente no Brasil. A idéia reinante era de que, havendo recursos e vontade política, a imensa maioria das doenças poderia ser controlada, senão eliminada. Foi nesse período que a febre amarela urbana foi eliminada do Brasil através do controle do seu vetor, o $A$. aegypti.

\section{DOS GOVERNOS MILITARES AOS DIAS DE HOJE}

Quando ocorreu o golpe militar de 1964, o contexto das doenças virais era muito diferente do de hoje, pelo menos na aparência. A dengue não existia no país e a febre amarela passava por um período de acalmia. A Aids não existia e as hepatites C, 
B e delta eram desconhecidas, embora pelo menos as duas últimas já estivessem presentes. A influenza não fazia parte das preocupações da saúde pública e as viroses gastrointestinais e respiratórias não eram reconhecidas. Se fosse perguntado a um sanitarista da época quais eram as viroses de maior impacto em saúde pública, ele provavelmente não teria ido além da febre amarela, da varíola e, talvez, da poliomielite, mesmo assim entenderia que estavam controladas.

Essa não era uma característica exclusivamente brasileira. A percepção dominante na saúde pública mundial era de que as doenças infecciosas, as virais inclusive, estavam em vias de controle ou mesmo de desaparecimento. Reinava a ilusão de que a disponibilidade de antimicrobianos, inseticidas e vacinas permitiria alcançar essa meta em pouco tempo e sem muito esforço. Esse pensamento levou ao gradual enfraquecimento dos programas de controle das doenças transmissíveis, uma decisão que o mundo viria a se arrepender mais tarde.

Em 1968, intensificou-se no Brasil o programa de erradicação da varíola, com o último caso ocorrendo em 1972. A campanha de erradicação da doença, seguida dos programas de erradicação da poliomielite e do sarampo, foi fundamental para a formação no Brasil de um sistema de vigilância epidemiológica que hoje, ainda que longe do ideal desejado, se equipara ao dos países desenvolvidos, permitindo ter, a cada momento, um retrato confiável da ocorrência das doenças de impacto em saúde pública. A varíola não apresenta risco de reintrodução, pelo menos por meios naturais. A reintrodução da doença como ato de bioterrorismo recebeu muita atenção nos últimos anos, particularmente depois do atentado de 11 de setembro de 2001, em Nova York. 
A poliomielite também foi erradicada no final da década de 1980, e certificada alguns anos depois. A reintrodução da poliomielite é teoricamente possível, uma vez que a doença continua ocorrendo em determinadas regiões do norte da Índia e da África subsaariana. Mas a cobertura vacinal contra a poliomielite da população infantil brasileira é elevada, fazendo com que esse risco seja muito pequeno. Quanto ao sarampo, não há evidências da circulação do vírus no Brasil em anos recentes, não obstante algumas reintroduções que foram controladas. Os vírus isolados durante esses surtos foram sempre de cepas circulantes em outras partes do mundo.

As duas últimas décadas podem ser vistas como um período de paradoxos da saúde pública brasileira. A mortalidade infantil caiu e continua caindo, e a expectativa de vida aumentou. Doenças foram controladas e erradicadas, outras emergiram e se tornaram epidêmicas. Essa situação não é peculiar ao Brasil e pode ser encontrada, com certas diferenças, em diversos outros países do mundo, sejam desenvolvidos, sejam em desenvolvimento. $\mathrm{O}$ controle das doenças virais, emergentes ou não, não pode ser dissociado de medidas semelhantes em outros países.

Duas viroses foram erradicadas no Brasil em época recente: a varíola e a poliomielite. O sarampo foi eliminado, mesmo que ocasionalmente ocorram reintroduções periódicas - ainda assim, esses episódios têm sido controlados de maneira eficaz. Foi em época recente, porém, que duas importantes viroses emergiram no Brasil: a dengue e a Aids, mudando significativamente o panorama da saúde pública brasileira.

Uma análise superficial e, infelizmente, freqüente, leva à conclusão de que o grande determinante para a emergência dessas viroses, assim como de outras, teria sido a deterioração dos 
programas de saúde pública. Essa é uma explicação simplista e, de certa maneira, atraente, por atribuir ao governo a responsabilidade pelos problemas. A verdade é mais complexa. Como veremos adiante, a dengue surge como conseqüência da reintrodução do $A$. aegypti, em parte por um lapso das ações de vigilância. A disseminação do vetor por, virtualmente, todo o país é muito mais resultado do crescimento desordenado das cidades brasileiras ao longo da segunda metade do século XX, crescimento este que impede o controle efetivo do $A$. aegypti apesar dos recursos despendidos. 



\section{I Arboviroses no Brasil Contemporâneo}

As arboviroses são viroses emergentes por natureza. Nenhuma delas é originariamente uma doença de humanos e somente se tornam importantes quando alguma modificação ecológica significativa altera seu habitat natural e leva a modificações de reservatórios, vetores e mesmo virulência.

O processo de desenvolvimento econômico, crescimento populacional e urbanização verificado no Brasil a partir da segunda metade do século XX colocou as arboviroses entre as viroses de grande impacto, real ou potencial, na saúde pública.

O termo arbovirose foi cunhado na década de 1930, quando diversos vírus foram isolados em artrópodes (daí o nome: 'ar'thropod 'bo'rne virus, vírus carreados por artrópodes), geralmente mosquitos, mas também carrapatos, pulgas e outros. Esses vírus têm em comum um ciclo que geralmente incluiu um reservatório animal, ave ou mamífero e um vetor artrópode, às vezes mais de um reservatório ou vetor. Em algumas situações, essas viroses acometem humanos, umas mais freqüentemente e com mais intensidade, como a febre amarela e a dengue. Elas são, originariamente, zoonoses, isto é, doenças de animais que apenas eventualmente acometem humanos. Em algumas, a adaptação aos humanos, do vírus ou do vetor artrópode, é suficiente para tornar o reservatório animal desnecessário para a manutenção do ciclo do vírus na natureza. 
Esse é o caso da dengue, originariamente uma doença de macacos e transmitida por diferentes espécies de culicídeos. A doença adaptou-se à transmissão de humano para humano em algum momento da história, encontrando no $A$. aegypti um vetor biológica e ecologicamente adequado, tanto que, atualmente, dengue em macacos pode ser encontrada apenas em algumas florestas da África e da Ásia.

Arbovírus e arboviroses estão presentes em praticamente qualquer ecossistema onde seja possível a presença de artrópodes. Embora as florestas mais densas e com maior pluviosidade sejam os ecossistemas mais ricos em arbovírus, eles podem ser encontradas também no cerrado. No Brasil, a Mata Atlântica (ou o que resta dela) e a floresta Amazônica são os maiores reservatórios de arboviroses. O Instituto Evandro Chagas, em Belém (PA), importante centro de estudos em arbovírus, isolou 187 diferentes espécies de vírus entre 1954 e 1998, a maioria no estado do Pará.

As arboviroses de interesse humano descritas no Brasil, excetuadas a febre amarela e a dengue, são possivelmente todas autóctones, existindo há muito tempo. São quatro os principais arbovírus que determinam epidemias e surtos no Brasil: febre amarela, dengue, oropouche e mayaro. Os demais são usualmente encontrados em forma esporádica, em casos isolados, como os vírus da encefalite eqüina venezuelana, encefalite eqüina do leste e encefalite de Saint Louis. Um outro vírus, Rocio, causou pelo menos uma epidemia no litoral paulista, em 1975, e permanece na Mata Atlântica, em pássaros.

\section{FEBRE AMARELA}

A febre amarela é uma doença infecciosa não contagiosa causada por um arbovírus mantido em ciclos silvestres, na África 
subsaariana e na América do Sul (do sul do Panamá ao norte da Argentina), onde macacos atuam como reservatório, sendo transmitida por mosquitos dos gêneros Aedes, na África, e Haemagogus e Sabethes, na América. Cerca de 90\% dos casos da doença apresentam-se com formas clínicas benignas que evoluem para a cura, enquanto $10 \%$ desenvolvem quadros dramáticos com mortalidade em torno de $50 \%$. A febre amarela pode apresentar um ciclo urbano, com transmissão de humano a humano, pelo $A$. aegypti, o mesmo vetor da dengue. Nas Américas, o último caso de febre amarela urbana foi em Trinidad, na década de 1950. Na África, surtos urbanos e periurbanos continuam acontecendo. A OMS estima que ocorram cerca de duzentos mil casos anuais, a maioria dos quais na África.

A primeira descrição de uma epidemia certamente por febre amarela no Brasil foi em Pernambuco, em 1685, vinda possivelmente da região do golfo do México. Essa introdução acometeu também Salvador, porém, a partir de século XVIII, não há relato da doença (o que não significa que não estivesse ocorrendo). Foi somente em meados do século XIX que as epidemias de febre amarela voltaram, agora no Rio de Janeiro, onde ocorreriam com certa regularidade até o seu controle no início do século XX.

A febre amarela pode ser considerada a doença símbolo da história da saúde pública brasileira, dado o impacto das epidemias urbanas que percorreram o país de meados do século XIX até o verão de 1928, quando se deu a última epidemia urbana de febre amarela no Brasil, no Rio de Janeiro (em 1942, se verificou o último caso urbano da doença, em Sena Madureira, Acre).

Como mencionado anteriormente, a febre amarela não é autóctone da América: foi introduzida depois da chegada dos 
europeus, através do grande tráfico de pessoas e mercadorias entre a América e a África. Uma vez aqui, em algum momento, se adaptou ao ambiente silvestre.

Ainda que a imagem da febre amarela seja a de uma doença da floresta tropical, amazônica, a maioria dos casos de febre amarela silvestre no Brasil ocorreu, e ocorre ainda, na bacia do rio Paraná.

O registro da febre amarela silvestre no Brasil é feito a partir da década de 1930. Desde então, ciclos razoavelmente regulares, com aumento do número de casos humanos e intervalos de aproximadamente cinco anos, vêm ocorrendo, sugerindo uma dinâmica peculiar de transmissão entre macacos. O primeiro surto de febre amarela silvestre registrado teve início em 1934 (1934 a 1940), repetiu-se em 1944 e 1945, de 1950 a 1953, de 1957 a 1959, em 1964, em 1973 e 1974, de 1982 a 1984, em 1993, a partir de 1998 e, mais recentemente, no verão de 2007-2008, com casos na Argentina e no Paraguai.

O início de 2008 foi marcado por um alarme, de grande impacto na opinião pública, sobre o crescimento dos casos de febre amarela silvestre, um acontecimento, de certa maneira, esperado, dado o comportamento cíclico desses surtos. Desde o ano 2000, a vigilância da febre amarela se estendeu para macacos encontrados mortos, e a detecção da febre amarela nestes animais atesta esse comportamento cíclico. O número de casos confirmados ou suspeitos em macacos no Brasil, assim como na Argentina e no Paraguai, excedeu em muito o número de casos em humanos, indicando que a transmissão da doença se dá com grande intensidade nas áreas silvestres. Durante esse surto, ocorreram casos de transmissão urbana no Paraguai, mas, ao contrário de um temor generalizado, isso não se transformou 
em epidemia de grande porte. Tal fato levanta a discussão do risco de urbanização da febre amarela.

Desde que o $A$. aegypti foi reintroduzido no Brasil e se disseminou por todo o país, já no início da década de 1970, a possibilidade da urbanização da febre amarela é assunto de discussão. Do ponto de vista teórico, essa possibilidade existe desde que o A.aegypti esteja presente, assim como um humano seja infectado pelo vírus. Apesar da extensa disseminação do vetor por todo o país, chegando às vezes a intensidades elevadas, e da ocorrência de inúmeros casos de febre amarela silvestre, a urbanização não ocorreu.

Qual a dimensão desse risco? Difícil calcular. Na prática, deve ser relativamente baixo, uma vez que no Paraguai ocorreram casos de transmissão urbana, mas foram poucos e não se verificou uma epidemia. De qualquer maneira, a possibilidade existe e deve ser levada em conta. Antes dessa ocorrência, um pequeno surto de febre amarela urbana havia sido descrito na Bolívia, em Santa Cruz de la Sierra, com poucos casos. O governo da Bolívia negou que houvesse transmissão urbana, mas o surto foi publicado numa revista médica de renome. Evidentemente, a dúvida persiste.

Qual seria a razão (ou as razões) para a não urbanização da febre amarela no Brasil e em outros países da América do Sul? Inicialmente, se colocou em questão a capacidade das variantes atuais do $A$. aegypti em transmitirem a febre amarela. Essa possibilidade foi afastada após estudos experimentais que demonstraram que as variantes atualmente existentes são perfeitamente capazes de transmitir o vírus da febre amarela.

Outra possibilidade, muito provável, seria que a disseminação da dengue no país, já tendo infectado milhões de pessoas vivendo nas cidades, seria um fator de proteção. Não se trata aqui de 
aceitar que uma infecção prévia pela dengue proteja contra a febre amarela, porém, a presença de anticorpos contra a dengue é suficiente para diminuir a quantidade de vírus na circulação sangüínea, reduzindo a possibilidade de infectar o $A$. aegypti. Isso pode ser demonstrado experimentalmente.

No início do século XXI, com a possibilidade da urbanização da febre amarela em vista, o Ministério da Saúde procurou levar a cabo a vacinação de toda a população brasileira de maneira gradativa, uma vez que não haveria vacina suficiente para realizar uma campanha de massa, caso necessário. Essa medida teria como resultado a criação de uma imunidade que impediria a ocorrência de surtos ou epidemias urbanas, ainda que casos isolados pudessem ocorrer. Infelizmente, essa abordagem logo teve de ser abandonada devido à ocorrência de eventos adversos graves, letais, causados pela vacina de febre amarela. Esses eventos são raros, talvez da ordem de um para cada milhão de vacinas aplicadas em pessoas não anteriormente vacinadas. Contudo, a vacinação da maioria da população brasileira viria a determinar diversos casos fatais.

$\mathrm{Na}$ década de 1930, quando o sanitarista norte-americano Fred Soper, da Fundação Rockefeller, mostrou que a febre amarela era uma zoonose, o modelo da epizootia se disseminando do norte para o sul era o consenso da época. Essa foi uma discussão interessante: se a febre amarela, quando se verificam as epizootias de macacos, 'caminha', isto é, vai se disseminando de uma área para a outra, ou se ela simplesmente apresenta uma maior intensidade de transmissão de maneira simultânea em diferentes lugares. Esse conceito se manteve até recentemente, quando a análise genética dos vírus isolados em diferentes lugares mostrou diferenças significativas, apontando 
para o fato de que não ocorria a disseminação do vírus em longas distâncias; ao contrário, existem focos silvestres que se mantêm latentes e, em resposta a algum fator (ou fatores), se dá a epizootia que acaba levando a casos humanos.

A febre amarela silvestre não pode ser controlada. Trata-se de uma doença de macacos, transmitida na mata. Os casos humanos, no entanto, podem ser prevenidos pela vacinação.

\section{Dengue}

Se a febre amarela foi por décadas a Nêmesis da saúde pública brasileira, podemos dizer que esse lugar foi ocupado pela dengue há pouco mais de uma década. A OMS estima que ocorram anualmente mais de cinco milhões de casos em todo o mundo, com cerca de 15 mil óbitos. Apesar de relativamente benigna, quando se verifica a co-circulação de diferentes sorotipos do vírus da dengue, a ocorrência de casos graves e, conseqüentemente, de óbitos pode aumentar. Esse fato se verifica no Brasil de hoje.

Segundo o Ministério da Saúde:

A Secretaria de Vigilância em Saúde do Ministério da Saúde (SVS/MS) registrou, em 2008 até semana epidemiológica 14, 230.829 casos suspeitos de dengue, 1.069 casos confirmados de febre hemorrágica da dengue (FHD) e a ocorrência de 77 óbitos por FHD, resultando em uma taxa de letalidade para FHD de 7,2\%. Também foram notificados 3.298 casos de dengue com complicação, com 53 óbitos. (Brasil, 2008)

A dengue provavelmente existiu no Brasil desde o período colonial. Doença originariamente africana, teria sido introduzida da mesma maneira que a febre amarela, uma vez que o seu vetor é o mesmo da febre amarela urbana, o $A$. aegypti. Existem relatos 
de epidemias e surtos de dengue nas regiões do golfo do México e do Caribe, e mesmo nas cidades norte-americanas da Filadélfia e de Nova York a partir do século XVIII.

No Brasil, aparentemente, a doença não teve grande impacto, seja pelo número pequeno de casos ou por ser relativamente benigna, levando a poucos óbitos na maioria das vezes. De qualquer maneira, há evidências confiáveis de sua presença no século XIX e de pelo menos uma epidemia em Niterói (RJ), em 1923.

Com a erradicação do $A$. aegypti na década de 1950, desapareceu a possibilidade de ocorrência de casos de dengue no Brasil. Entretanto as epidemias continuaram freqüentes em áreas da América onde o $A$. aegypti ainda era encontrado (países do Caribe, da América Central e do norte da América do Sul). Nos Estados Unidos, as epidemias de dengue, comuns na costa do golfo do México, deixaram de ocorrer na década de 1950.

Com a reinfestação das cidades brasileiras pelo $A$. aegypti a partir do início da década de 1970, o risco de reintrodução da dengue se torna uma possibilidade concreta, mas foi somente em 1981 que uma epidemia pelos sorotipos 1 e 4 ocorreu no então território de Roraima. A introdução do vírus provavelmente se deu a partir da vizinha Venezuela, entretanto a doença não se disseminou para o resto do país.

A partir de 1986, sucessivos surtos de dengue passaram a ocorrer em diversas cidades brasileiras, desde a região Norte até o estado do Paraná, na região Sul. Inicialmente, Rio de Janeiro e Fortaleza foram os centros mais acometidas. Até 1994, esses surtos eram relativamente pequenos, com pouquíssimos casos graves e raros óbitos, possivelmente porque, até 1990, quando foi introduzido o sorotipo 2, a circulação era exclusivamente do sorotipo 1. 
Em 1998, o Brasil sofreu a maior sucessão de surtos e epidemias, com mais de quinhentos mil casos, pouco menos do que em 2007, sem dúvida o ano não só com o maior número de casos mas também de óbitos.

A perspectiva para a dengue no Brasil não é animadora. $O$ comportamento da doença no Sudeste Asiático também mostra uma tendência crescente, tanto em número de casos quanto em gravidade, desde o início da década de 1950 até os dias de hoje, quando a dengue é uma das principais causas de mortalidade infantil em determinados anos.

O Brasil sofreu recrudescimentos da doença a cada introdução de um novo sorotipo e ainda não sofremos a disseminação do sorotipo 4, ainda que esse circule no norte da América do Sul. Recentemente foi publicado, numa revista internacional sobre doenças emergentes, um artigo de pesquisadores de Manaus relatando o caso de pessoas infectadas pelo vírus do sorotipo 4 . $\mathrm{O}$ vírus não foi isolado; foi detectado através de métodos de biologia molecular. O Ministério da Saúde contestou o achado, instalando-se a polêmica.

A epidemia de dengue, no início de 2008, no Rio de Janeiro, assim como outros surtos em diversos estados brasileiros, é a comprovação do que se esperava. Estas epidemias vêm se tornando mais graves e acometendo proporcionalmente mais crianças à medida que se repetem ano após ano, como veremos a seguir.

\section{Determinantes da atual Situação da dengue NO BRASIL}

Diversos são os fatores associados à ocorrência das sucessivas epidemias de dengue, incluindo-se a introdução de novos sorotipos e, possivelmente, genótipos, alterações climáticas 
(elevação das médias de temperatura, pluviosidade), deficiências dos sistemas de saneamento básico e oferta de águas, baixo nível socioeconômico e cultural.

A circulação de dois ou mais sorotipos e altas taxas de infestação pelo vetor Aedes, levando à situação de hiperendemicidade, propicia tanto a ocorrência de epidemias quanto o maior risco de infecção por mais de um sorotipo. Atualmente, está bem estabelecido que, uma vez infectado por um sorotipo, isso proporciona imunidade duradoura contra o sorotipo infectante. Entretanto, infecções sucessivas em um mesmo indivíduo são incriminadas como o maior fator predisponente para as formas hemorrágicas da dengue.

A infecção pelo vírus da dengue, após um período de incubação de dois a oito dias, define quatro grupos de quadros clínicos:

- infecções assintomáticas;

- dengue clássica: geralmente benigna, com presença de cefaléia, dores musculares, dores articulares, exantema, diarréia e vômitos;

- dengue hemorrágica: responsável pelo número crescente de casos graves e óbitos, geralmente associada a hemorragias e alterações hemodinâmicas, levando à queda de pressão arterial (no extremo mais grave, define a síndrome do choque da dengue);

- dengue com complicações: associada a manifestações, freqüentemente graves, mas menos comuns (por exemplo, hepatite e manifestações neurológicas).

Tendência já observada em áreas que convivem com a dengue endemicamente, o incremento progressivo da doença na faixa etária pediátrica, incluindo-se a dengue hemorrágica, passou a ser também observado no Brasil. 
A evolução da dengue no país desde meados da década de 1980 até os dias atuais é um clássico exemplo da epidemiologia dessa doença. Para melhor entender a situação atual, é necessário voltar atrás algumas décadas e deslocar nossa atenção para o Sudeste Asiático.

A dengue sempre foi uma causa de surtos e epidemias, mas essas eram geralmente de pouca gravidade. Cabe lembrar que existem quatro sorotipos do vírus da dengue, denominados dengue 1, 2 e assim por diante (DEN-1, DEN-2, DEN-3, DEN-4), e que a infecção por cada um deles confere imunidade permanente contra outras infecções pelo mesmo tipo, mas não contra infecções pelos demais. No caso da dengue e de outras doenças transmitidas por vírus (por exemplo, pelo vírus do sarampo e pelo vírus sincicial respiratório), ocorre um fenômeno imunológico conhecido como facilitação por anticorpos.

$\mathrm{Na}$ dengue, devido ao seu caráter epidêmico, esse fenômeno assume proporções equivalentes ao número de casos verificados anualmente em todo o mundo. $\mathrm{O}$ fenômeno pode ser entendido da seguinte maneira: quando ocorre uma infecção viral, o organismo desenvolve anticorpos de diferentes naturezas, que vão bloquear a infecção com maior ou menor eficiência. Os mais eficientes são os denominados anticorpos 'neutralizantes'. São altamente específicos e capazes de neutralizar, ou seja, inativar um vírus, abortando a infecção. A ligação de um anticorpo neutralizante inviabiliza o vírus e cria um complexo vírus-anticorpo que facilita a fagocitose por células do sistema imunitário (linfócitos e macrófagos) no interior das quais serão destruídos.

Por 'específicos' entenda-se que se ligam e neutralizam única e exclusivamente vírus de determinada característica antigênica. No caso da dengue, os anticorpos neutralizantes contra o vírus 
DEN-1 se ligam e inativam unicamente o DEN-1; os anticorpos neutralizantes contra o DEN-2, apenas o DEN-2; e assim por diante. É por este motivo que uma infecção pelo vírus da dengue induz proteção contra infecções subseqüentes, mas apenas contra o mesmo tipo.

Outros anticorpos menos específicos são capazes de se ligar ao vírus, porém atuam de maneira menos eficaz na sua inativação. Por serem menos específicos, se ligam também aos diferentes tipos do vírus da dengue. Por exemplo, uma infecção pelo DEN-1 induz a formação de anticorpos neutralizantes e outros nãoneutralizantes. Os neutralizantes, como já foi mencionado, são específicos: se ligam e neutralizam apenas o mesmo sorotipo. Os não-neutralizantes, no entanto, se ligam aos outros sorotipos, porém são incapazes de inativá-los. Na maioria das doenças virais, isso não tem maiores implicações. Já na dengue, essa ligação de anticorpos aos vírus sem inativação determina um complexo que facilita a fagocitose por células do sistema imunitário, porém, como o vírus não está inativado, se replicará no interior das células causando um processo inflamatório sistêmico.

Estes fatores explicam por que uma infecção por um vírus da dengue em uma pessoa previamente infectada pelo vírus, embora de outro sorotipo, pode acabar provocando uma infecção mais grave, devido ao papel facilitador da fagocitose, sem inativação, dos vírus, levando a um número muito maior de células infectadas e, conseqüentemente, a um processo inflamatório mais intenso, muitas vezes letal.

Essa teoria, desenvolvida há algumas décadas por um pesquisador de nome Halstead, explica por que, nos locais onde circulam dois ou mais tipos do vírus da dengue, as epidemias são mais graves, com maior número de mortes. As formas graves 
da dengue são, geralmente, a dengue hemorrágica e a síndrome do choque da dengue, um aspecto relativamente recente na história da doença.

Dengue como doença grave é uma característica da segunda metade do século XX. A explicação epidemiológica para o fato é que, até então, os diferentes sorotipos da dengue circulavam em áreas distintas, ainda que todos pudessem ser encontrados no mesmo continente, porém a circulação simultânea de vários tipos era rara e restrita.

Depois do final da Segunda Guerra Mundial, com a descolonização do Sudeste Asiático, o crescimento demográfico acelerado e, principalmente, a urbanização e as migrações determinadas por motivos econômicos e por guerras locais, os diferentes tipos de dengue passaram a circular concomitantemente. Esse fenômeno determinou as primeiras epidemias graves de dengue no Sudeste Asiático, com elevada mortalidade. Na América, isso demorou a ocorrer: ao longo das décadas de 1950 e 1960, fez-se uma intensa campanha de erradicação do $A$. aegypti, levando ao quase desaparecimento da dengue no continente.

O progressivo agravamento das epidemias de dengue ao longo dos anos se explica pelo aumento de pessoas infectadas por um ou mais sorotipos. Além disso, os recém-nascidos de mães que têm anticorpos contra a dengue recebem esses anticorpos, que permanecem circulantes por meses, geralmente desaparecendo ao longo do primeiro ano de vida. Esses lactentes, no entanto, se comportam como pessoas previamente infectadas. Por isso, a dengue, quando diferentes sorotipos circulam simultaneamente numa população, tende a determinar epidemias que se agravam com o passar dos anos e se verifica uma tendência de ocorrerem casos graves em lactentes com uma freqüência 
cada vez maior, à medida que um número cada vez maior de mulheres em idade fértil foi infectado por pelo menos um dos sorotipos.

Estabelecidos os determinantes vinculados ao vírus, cabe entender o papel do vetor da dengue. $\mathrm{O} A$. aegypti coloca seus ovos em recipientes com água limpa, na sombra e próximo dos domicilios humanos. A adaptação do $A$. aegypti ao meio urbano é impressionante. Esse mosquito prefere criadouros artificiais a criadouros naturais, e a fêmea se alimenta de sangue apenas de humanos (o macho se alimenta da seiva de plantas).

Costuma-se comparar o sucesso das campanhas de controle do A. aegypti na virada do século XX, quando Emílio Ribas, em São Paulo, controlou epidemias de febre amarela em Sorocaba e Ribeirão Preto, com o fracasso das atuais medidas. Entretanto, a situação era outra. Bons tempos aqueles: ausência de caminhões e estradas de rodagem, trens saindo com horário controlado, poucas mercadorias sendo transportadas, café saindo e produtos industrializados entrando. Nada de recipientes de plástico, nem artigos descartáveis. As únicas embalagens descartáveis na época eram as cascas dos ovos e das bananas. A urbanização era incipiente e a população, idem.

Recipientes de plástico, pneus, latas e um sem-número de produtos descartados como lixo pela sociedade moderna formam o substrato em que o mosquito prolifera. A eclosão das larvas não é imediata: os ovos são colocados pouco acima da linha da água e, quando chove, o nível sobe, atingindo os ovos, que então eclodem. A quantidade desses criadouros potenciais é imensa. Recipientes de plástico, latas de cerveja e refrigerantes e pneus são produzidos aos milhões e apenas uma parcela desses é devidamente reciclada ou recebe o destino final. 
Eliminar o A. aegypti do Brasil hoje, tal como foi feito na década de 1950, é impossível. Devemos aceitar que eliminar a dengue não será possível na ausência de uma vacina. Quando na década de 1950 o Brasil erradicou o $A$. aegypti, o vetor urbano da febre amarela e da dengue levou menos de dez anos e empregou, em todo o país (excetuando-se o estado de São Paulo), cerca de 3.500 agentes no período de maior atividade. Éramos pouco mais de cinqüenta milhões de habitantes, a maioria dos quais na área rural ou em pequenas cidades. Não se pode comparar os excelentes resultados conseguidos por Emílio Ribas e Oswaldo Cruz no início do século XX, nem os dos serviços de saúde pública na metade do mesmo século, com a situação dos dias atuais.

Cabe, portanto, aprender a conviver com o $A$. aegypti e a dengue. Do comportamento do $A$. aegypti tiramos duas lições importantes. Em primeiro lugar, a erradicação do mosquito ou seja, fazê-lo desaparecer da face da Terra ou pelo menos do país - é tarefa muito difícil, senão impossível.

O Brasil é, hoje, um país de população predominantemente urbana e a indústria gera uma quantidade crescente de produtos que serão posteriormente descartados, criando condições para a proliferação do mosquito. O transporte de mercadorias é intenso, não havendo um sentido único como no passado. Atualmente, entram e saem produtos industrializados, entra e sai produção agrícola. Pneus, para serem recauchutados, vão de Campinas para Goiás e vice-versa, quando não são importados do Japão. A proliferação de loteamentos e construções irregulares desafia qualquer tentativa de controle, não só em Campinas. Invasões e acampamentos estão sempre à frente da infra-estrutura urbana. Eliminar um mosquito excepcionalmente bem adaptado 
a este meio quase caótico implica coordenar uma atividade simultânea não só no país como também em todo o continente, além de exigir uma sistemática de controle e vigilância.

A segunda lição, talvez a mais importante, é que as epidemias de dengue não são combatidas, e sim prevenidas. O recolhimento de recipientes deve ocorrer antes do período das chuvas e ser objeto de uma atuação constante, visando a mudar um comportamento sabidamente difícil de ser alterado. Devemos introduzir a noção de ambiente seguro, pelo menos no que diz respeito a mosquitos. Incentivar a compra de recipientes usados de plástico e de latas, não como campanhas episódicas, mas como uma atividade comercial legítima, com apoio financeiro e supervisão técnica do poder público, criaria um fluxo natural de lixo reciclável, além de contribuir para a redução do desemprego.

Devemos acabar com a ilusão de que a dengue é passível de eliminação em curto prazo. Estamos destinados a conviver com mais esta doença, queiramos ou não. O seu controle não está nas ações clássicas de saúde pública. Compra de veículos e equipamentos para borrifar inseticidas, contratação de funcionários e confecção de cartazes são medidas de curto fôlego, pouca efetividade e alto custo, porém de alto impacto político.

Derrotar a doença exige uma tática de guerrilha, com mudança de comportamento da população - e, por que não, dos serviços de saúde - e a implantação de ações permanentes. A tônica da luta contra a Aids é a mudança de comportamento, a introdução do conceito de sexo seguro, não a eliminação do relacionamento sexual. Por que não levantar a bandeira do 'ambiente seguro', um ambiente em que as doenças não teriam como se disseminar? A dengue, infelizmente, veio para ficar. 
Cabe reduzir os riscos que a sua existência traz, e não existe uma fórmula rápida e fácil.

\section{OUtROS FLAVIVÍRUS}

O vírus Rocio foi primeiramente isolado durante epidemia iniciada em 1973 em área de Mata Atlântica no Sudeste brasileiro, que se estendeu até 1980. Nesse período, cerca de mil casos de encefalite foram notificados. Assim como em outras arboviroses previamente discutidas, o ciclo do vírus Rocio no ambiente silvestre possivelmente envolve aves como reservatórios e mosquitos, incluindo o gênero Aedes como vetores.

$\mathrm{O}$ vírus causador da encefalite de Saint Louis se encontra amplamente distribuído por todo o continente americano, tendo sido descrito pela primeira vez no Brasil em 1960. Até o ano de 2004, casos isolados foram relatados. Entretanto, em 2006, doze casos humanos de encefalite de Saint Louis foram diagnosticados na região noroeste do estado de São Paulo, desencadeando a estruturação da vigilância epidemiológica, permanente para esse agravo, naquela região. Clinicamente, além de um quadro neurológico variável (alterações de equilíbrio, confusão mental, crises convulsivas), a presença de febre, cefaléia, prostração e mialgia na maioria dos casos justifica a inclusão desse agravo como possível diagnóstico diferencial da dengue. Assim como para a imensa maioria das arboviroses, vacinas preventivas e tratamentos não estão disponíveis até o momento. 


\section{OUtros ARBOVÍRUS}

\section{Buniavírus}

Os buniavírus recebem esse nome pelo vírus Bunyamwera, isolado de um paciente na localidade do mesmo nome, em Uganda. Os quadros clínicos determinados pelos vírus desse gênero variam de síndromes febris indiferenciadas, geralmente benignas, até encefalite.

Dos mais de quinhentos vírus listados no Catálogo Internacional de Arbovírus, cerca de 313 pertencem à família Bunyaviridae, uma das maiores famílias de vírus, o que representa um desafio para os taxonomistas. Muitos são transmitidos por mosquitos, mas com diferentes hospedeiros vertebrados, e mais de sessenta foram identificados como causando doença em humanos ou em animais de interesse econômico.

Apresentam características morfológicas semelhantes, são RNA vírus com envelope lipídico com filamentos únicos de RNA, na maioria das vezes de senso negativo, dividido em três segmentos.

A maioria consiste de arbovírus, os vetores artrópodes são mosquitos, moscas e carrapatos e os hospedeiros vertebrados são principalmente roedores, mas também pequenos mamíferos, primatas, aves e ungulados.

Os Bunyaviridae estão distribuídos em cinco gêneros, três dos quais de vírus transmitidos por artrópodes: Orthobunyavirus, Phlebovirus, Hantavirus, Tospovirus e Nairovirus.

Oropouche

No Brasil, o vírus Oropouche é uma das causas mais freqüentes de febre inespecífica nas regiões Norte e Centro-Oeste 
do país. São transmitidos por vetor alado. O vírus Oropouche, principal representante do gênero Orthobunyavirus (família Bunyaviridae) é um buniavírus do subgrupo Sinmbu.

Descrito pela primeira vez em 1955, na ilha de Trinidad (mar do Caribe, próxima à costa da Venezuela), o primeiro surto urbano ocorreu em 1961, em Belém (PA), com cerca de 11 mil casos. Dezenas de surtos foram descritos desde então, na região Amazônica e no Centro-Oeste, com alguns determinando até cem mil casos. Depois da dengue, é a arbovirose mais comum no Brasil, provocando surtos também em outros países, como Panamá e Peru.

Causa uma doença febril, sem características especiais, geralmente benigna, com três a cinco dias de duração. Transmitido por mosquitos silvestres dos gêneros Aedes serratus e Culex quinquefasciatus, pode ser encontrado no bicho-preguiça, no coati e em sagüis. À semelhança de outros arbovírus, como o da febre amarela e o da dengue, o Oropouche se adaptou a um ciclo urbano, transmitido de humano a humano e transmitido pelo Culicoides paraensis (conhecidos como maruins e mosquitospólvora).

Como o C. paraensis é amplamente encontrado pelo Brasil, a possibilidade de disseminação do vírus Oropouche para outras regiões além do Norte e Centro-Oeste é real e difícil de prever ou mesmo prevenir. Não existe vacina ou tratamento específico.

\section{Phlebovirus}

Phlebovirus é um gênero que consiste de mais de cinqüenta vírus, todos transmitidos por flebotomíneos. Não há representante conhecido no Brasil. As doenças mais importantes são a febre do Vale do Rift e a febre pappatacci, causada pelo vírus 
Toscana, encontrado na Europa mediterrânea. São transmitidos por vetor alado.

Os tospovírus são de vírus de plantas, e não há registro de nairovírus em humanos no Brasil. O principal vírus deste grupo é o da febre hemorrágica do Congo-Criméia, grave doença hemorrágica transmitida por carrapatos, encontrada na África subsaariana e na região do Cáucaso. Os hantavírus discutidos adiante, na seção sobre robovírus, não são transmitidos por artrópodes.

\section{Mayaro}

Menos comum em humanos do que o Oropouche, o vírus Mayaro também causa surtos de doença febril nas regiões Norte e Centro-Oeste do Brasil, assim como em outros países da América do Sul (Bolívia, Peru e Venezuela). Pertence ao gênero Alphavirus, família Togaviridae, juntamente com os vírus da encefalite eqüina venezuelana, encefalite eqüina do leste e Chikungunya (ver adiante).

A doença causada pelo vírus Mayaro é geralmente benigna, mas, diferentemente daquela provocada pelo Oropouche, pode ser temporariamente incapacitante, com freqüência causando exantema e artralgia ou mesmo artrite, mialgia e febre com duração de três a cinco dias. Durante a convalescença, muitas vezes a artralgia persiste algumas semanas.

O ciclo silvestre do vírus Mayaro é semelhante ao da febre amarela silvestre, sendo uma doença de macacos, transmitida por mosquitos do gênero Haemagogus. Além de macacos, o vírus Mayaro pode ser encontrado também em pássaros. Diferentemente do Oropouche, o vírus Mayaro não se adaptou a um ciclo urbano, ainda que isso possa ocorrer eventualmente. Não existe vacina ou tratamento específico. 


\section{$5 \mid$ Mais Viroses Emergentes}

Os arbovírus, discutidos no capítulo anterior, podem ser considerados um grupo 'clássico' de vírus, mantendo uma denominação de ordem epidemiológica e não taxonômica. A pressão das sociedades humanas sobre os ambientes naturais fez com que surgisse um novo conjunto de vírus agrupados por características epidemiológicas e não taxonômicas.

\section{ROBOVIROSES}

O termo robovírus, com sua derivação 'roboviroses', foi cunhado recentemente. Assim como arboviroses se referem às viroses transmitidas por carrapatos, robovírus e roboviroses dizem respeito aos vírus e às viroses por eles determinadas que são transmitidas por roedores (robovirus vem do inglês 'ro'dent 'bo'rne vírus). A transmissão por roedores se dá de forma indireta, através de aerossóis 'contendo' vírus, formados a partir de dejetos, fezes e urina deixados por roedores.

Dois grupos principais de vírus podem ser colocados nesta categoria, os arenavírus - vírus pertencentes à família Arenaviridae - e os hantavírus - vírus pertencentes ao gênero Hantavírus, da família Bunyaviridae.

Arenavírus

Os arenavírus são vírus de roedores, com exceção do vírus Tacaribe, um arenavírus de morcegos identificado em Trinidad, 
no Caribe. A transmissão se dá por inalação do vírus, geralmente na forma de aerossóis formados de dejetos em ambientes fechados ou por manipulação dos animais. Dada a sua alta virulência e patogenicidade, os arenavírus determinam um alto grau de risco biológico, devendo ser manipulados unicamente em laboratórios com, pelo menos, nível de biossegurança três.

As espécies dos reservatórios variam conforme o vírus. Com exceção do vírus da coriomeningite linfomonocitária, cujo reservatório é o camundongo urbano, Mus musculus e, eventualmente, o hamster, todos os demais são roedores silvestres.

Ainda que diversos arenavírus tenham sido identificados no Brasil, apenas um foi associado à doença humana e, mesmo assim, com raros casos. Ao contrário do que se verifica em outros países da América do Sul (Argentina, Bolívia e Venezuela), onde surtos de dimensão razoável já ocorreram.

Os arenavírus americanos pertencem a um mesmo grupo, conhecido como complexo Tacaribe. Apenas o vírus Sabiá, isolado de um paciente no estado de São Paulo, foi associado à doença humana. Os arenavírus causam um quadro sistêmico, grave, de elevada letalidade, com hemorragia disseminada, muito semelhante às manifestações de dois outros vírus (da famíla Filoviridae), encontrados na África e inexistentes nas Américas: os vírus Ebola e Marburg. Os roedores responsáveis pela circulação do vírus Sabiá na natureza ainda são desconhecidos, mas certamente se tratam de roedores silvestres, não urbanos.

A importância dos arenavírus no Brasil se deve muito mais ao risco potencial de surtos localizados, à semelhança do que já ocorreu em países vizinhos (Argentina, Bolívia e Venezuela). A única vacina existente contra um arenavírus é a utilizada na 
Argentina, contra o vírus Junin. Não há tratamento específico contra doença causada por arenavírus.

Hantavírus

Os hantavírus, juntamente com os arenavírus, são robovírus (vírus de roedores) e sua transmissão se dá pela inalação de aerossóis de vírus formados a partir de dejetos de roedores ou pela manipulação desses. O nome deriva do rio coreano Hantaan, em cujo vale soldados norte-americanos e aliados manifestaram uma doença febril, hemorrágica e com síndrome renal durante o conflito armado no início da década de 1950. Alguns anos depois, foi isolado o primeiro representante dos hantavírus, grupo com representantes encontrados desde a Europa Central e Escandinávia até a costa do Pacífico da Ásia. No início da década de 1990, foi isolado em vírus do mesmo grupo nos Estados Unidos, causando uma doença febril com insuficiência cardiorrespiratória e, às vezes, manifestações renais e hemorrágicas discretas. Na última década, surtos e casos isolados de síndrome cardiopulmonar por hantavírus (SCPH) têm sido identificados nas Américas, da Patagônia ao Canadá, com diferenças clínicas e epidemiológicas discretas e com pequenas variações.

As espécies dos reservatórios dos hantavírus variam conforme a região. Com exceção da variante Seul, do Extremo Oriente, encontrada em roedores urbanos, todos os demais hantavírus têm como reservatórios roedores silvestres. No Brasil, o Bolomys lasiurus e o Ologoryzomys nigripes são os principais reservatórios conhecidos.

Desde a descrição dos primeiros casos de SCPH nas Américas, em 1993, nos Estados Unidos, com a descoberta do vírus Sin Nombre, um número crescente de casos passou a ser 
documentado em vários estados daquele país, bem como em diversos países da América Latina.

No Brasil, o primeiro surto, com três casos, foi descrito em uma área rural de Juquitiba, estado de São Paulo, em 1993. Naquela ocasião, descreveu-se então pela primeira vez o hantavírus Juquitiba como agente etiológico. $\mathrm{Na}$ América Latina, além do Brasil e da Argentina, país com maior número de casos, Panamá, Chile, Paraguai, Uruguai e Bolívia vêm apresentando número crescente de casos diagnosticados de SCPH.

Diferentemente da SCPH da América do Norte, na América do Sul a SCPH vem mostrando algumas particularidades: ocorrência com grande freqüência na forma de surtos, possível transmissão pessoa-pessoa e alta proporção de crianças acometidas.

Nos Estados Unidos, estudos de soroprevalência indicam positividade variando de $0,2 \%$ a $1,7 \%$. A ocorrência nesse país já é descrita em pelo menos trinta estados, com maior concentração de casos no sudoeste do país.

$\mathrm{Na}$ América Latina, verificam-se soroprevalências em humanos variando de 1,7\%, na Venezuela, e 6,5\%, na Argentina, a 42,7\%, no Paraguai. Inquérito sorológico no Brasil, no município de Jardinópolis, estado de São Paulo, evidenciou soroprevalência de $14,3 \%$.

A possível explicação para as distintas prevalências encontradas em países da América Latina poderia estar associada à ocorrência de reação cruzada com hantavírus nãopatogênicos, à existência de cepas de hantavírus menos virulentas, à presença de formas clínicas leves, ao tipo de exposição ambiental envolvida e à possível constituição genética de populações específicas em cada área ou país. 
No Brasil, a SCPH, doença de notificação compulsória e de investigação obrigatória, vem se caracterizando por acometer com mais freqüência indivíduos adultos, jovens, masculinos, previamente hígidos e que apresentam atividades, sobretudo ocupacionais, em meio rural. Em relação à faixa etária, indivíduos de todas as idades vêm sendo acometidos. No Brasil, a média da faixa etária de pacientes com SCPH foi de 34 anos, variando de 8 meses a 66 anos. Apesar de vir ocorrendo em todos os meses do ano, observa-se uma maior incidência da doença no período de junho a dezembro. Surtos acontecem esporadicamente no Brasil, sendo o mais recente no Distrito Federal e nas cidades-satélite, em 2004.

No período de 1993 a agosto de 2004, 409 casos de SCPH foram notificados no Brasil. Todas as regiões apresentaram casos neste período, havendo maior prevalência nas regiões Sul e Sudeste, que notificaram, respectivamente, 179 e 144 casos. Dentre os estados, o Paraná é aquele que concentra o maior número de pessoas atingidas (92).

\section{VIROSES RESPIRATÓRIAS}

Desde a identificação do vírus sincicial respiratório como causa importante de infecções respiratórias em crianças, tem havido uma incessante busca de agentes virais causadores deste tipo de problema. Foram os últimos anos, no entanto, que trouxeram o maior número de novos agentes, mostrando também a possibilidade do surgimento de novas causas de infecções respiratórias. Fica muito difícil, senão impossível, saber se essas infecções são de fato emergentes ou, simplesmente, adquirimos a capacidade de identificá-las. 
O surto de infecções respiratórias pelo coronavírus humano, em 2003, ainda que tenha poupado a faixa pediátrica, demonstrou a possibilidade do salto de espécies, reforçando a necessidade de uma vigilância incessante. De qualquer maneira, com exceção da influenza e do vírus sincicial respiratório, as outras viroses respiratórias não apresentam tendência a determinar surtos e epidemias, ocorrendo numa freqüência relativamente estável.

As viroses respiratórias constituem uma importante causa de morbidade e mortalidade infantis. Não existe muita dúvida de que o maior impacto é causado pelo vírus sincicial respiratório e pelo vírus da influenza. Ambos determinam epidemias sazonais: o vírus sincicial começa por volta de fevereiro e se estende até meados do ano; as epidemias de influenza são mais concentradas, ocorrendo de junho a agosto, com pequenos surtos fora desse período. A epidemiologia da influenza nas áreas tropicais do país ainda é relativamente pouco conhecida, mas geralmente os surtos das áreas próximas ao Equador iniciam antes.

\section{Influenza}

A influenza, ou gripe, está longe de ser emergente no Brasil. Há evidências indiretas de sua ocorrência entre nós pelo menos desde o século XIX. Durante a pandemia de 1918, o Brasil foi duramente acometido, a exemplo da imensa maioria dos países do mundo. As três pandemias do século XX (1918, 1957 e 1968) causaram um impacto no Brasil equivalente ao verificado em outros países, sendo que os vírus pandêmicos foram isolados no Brasil em 1957 e 1968. Os vírus da influenza, no entanto, sofrem contínua modificação, podendo ser considerados como 'eternos emergentes'. 
A influenza é possivelmente a mais comum das viroses respiratórias. Universal na sua disseminação, acomete tanto países em desenvolvimento como os industrializados. A melhor vigilância e a maior importância atribuídas à influenza nos Estados Unidos e na Europa passam a impressão de que se trata de uma doença de países de clima temperado ou frio. Impressão falsa: a influenza ocorre tanto nas regiões tropicais como nas temperadas. A diferença reside no fato de que sazonalidade nos trópicos não é tão marcada como nas regiões temperadas. No Sudeste brasileiro, o vírus da influenza circula principalmente nos meses de junho, julho e agosto, mas casos isolados podem ser encontrados praticamente durante todo o ano.

A influenza é uma doença respiratória com acometimento sistêmico. Diferentemente do resfriado comum, que é localizado nas vias aéreas superiores, os vírus da influenza acometem todo o sistema respiratório, inclusive o inferior, podendo levar a quadros graves e fatais. Os extremos de idade são mais vulneráveis, mas pessoas de qualquer idade podem ser acometidas. Quem tem doença crônica, principalmente respiratória e cardíaca, sofre maior risco de complicações e óbito.

Os vírus da influenza têm aves aquáticas e migratórias como seu reservatório original na natureza. Classificados na família Orthomyxoviridae, são RNA vírus subdivididos em três grupos de vírus da influenza: A, B e C. Este último, ainda que já tenha sido associado a surtos de doença respiratória em crianças, tem mínima importância em saúde pública. São os vírus A e B que causam surtos e epidemias anualmente, particularmente o vírus A, capaz de causar também pandemias.

Das aves aquáticas, seu nicho original, os vírus da influenza se disseminaram e se adaptaram a diversas outras espécies animais, 
entre elas, as aves de interesse econômico, como patos, galinhas e perus, além de cães, cavalos, mamíferos marinhos (baleias, golfinhos), porcos e humanos. $\mathrm{O}$ processo de disseminação e adaptação repete-se periodicamente, isto é, não se deu uma única vez, como ocorreu com os vírus da dengue ou febre amarela.

\section{Bocavírus e metapneumovírus}

Recentemente, dois novos vírus respiratórios foram descritos: os bocavírus e o metapneumovírus. A presença de infecção por esses dois vírus já foi demonstrada em crianças no Brasil, numa freqüência não muito diferente da verificada em outros países. Com quase toda certeza, não se trata de vírus propriamente emergentes, mas de vírus previamente existentes, embora reconhecidos apenas há pouco tempo.

Descrito em 2005, o bocavírus humano (HBoV) pertence à família Parvoviridae. Até então, o parvovírus humano B19 (gênero Erythrovirus) era o único dessa família que se sabia causar infecção em humanos. O nome bocavírus deriva do fato de que o gênero contém apenas outros dois vírus, um canino e outro bovino ('bo'vine - 'ca'nine - virus).

O bocavírus humano foi isolado em secreções respiratórias e, posteriormente, em fezes de crianças com doença respiratória, ainda que, muitas vezes, em associação com outros vírus. Há relatos da presença de bocavírus em praticamente todo o mundo, inclusive no Brasil. A sua importância ainda está por ser estabelecida, mas tudo indica que já existia há muito tempo, não havendo risco aparente de surtos ou epidemias.

Ainda que inicialmente descrito em associação com doença respiratória, pode ser isolado de fezes de crianças com gastroenterite. A importância relativa dessas infecções ainda está por ser 
definida, porém há evidências de que seja relativamente pequena. A doença causada é difícil de ser diferenciada de outras viroses respiratórias, como as determinadas por metapneumovírus, parainfluenza ou outros.

\section{ViROSES GASTROINTESTINAIS}

Desde a descrição inicial dos rotavírus como causa importante de diarréia em crianças e mesmo em adultos, os vírus passaram a ser reconhecidos como relevantes tanto do ponto de vista clínico como de saúde pública. Sem dúvida, os norovírus, gênero da família Caliciviridae, formam o grupo de maior disseminação e de reconhecimento mais recente. Porém, o impacto em termos de morte e adoecimento, particularmente de lactentes e crianças até dois anos, é causado pelos rotavírus.

\section{Calicivírus}

Os norovírus, cujo primeiro representante identificado foi o então denominado agente Norwalk (agente etiológico de um surto de diarréia na cidade homônima do estado norte-americano da Virgínia), são hoje um gênero com pelo menos dois genótipos (I e II), cada um deles com quatro cepas reconhecidas.

Os norovírus são atualmente reconhecidos como os responsáveis por um número elevado de surtos em comunidades restritas, como escolas, navios de cruzeiro, hospitais, casas de repouso, restaurantes e refeitórios. Uma característica dos norovírus é acometer tanto adultos como crianças, indiferentemente.

Há um número suficiente de estudos no Brasil para aceitar que a ocorrência dos calicivírus é comum. Porém não permitem verificar se são de fato emergentes ou simplesmente não tinham anda sido reconhecidos. Mais recentemente, no entanto, uma nova 
variante do norovírus causou surtos em praticamente todo o mundo, o Brasil não sendo exceção. Ainda que os norovírus possam estar circulando entre nós há muitos anos, existe a possibilidade de introdução de novas variantes, com recrudescimento dos surtos em número e intensidade.

\section{Rotavírus}

Principal causa de diarréia em lactentes e crianças pequenas, os rotavírus determinam pelo menos $40 \%$ dos casos de diarréia em todo o mundo, causando cerca de seiscentas mil mortes em crianças, a maioria abaixo dos dois anos de idade. No Brasil, a situação não difere. Descobertos há pouco mais de 35 anos, os rotavírus causam surtos e epidemias mesmo nos países industrializados, geralmente durante o inverno.

Impossível determinar quando teriam surgido ou mesmo sido introduzidos no Brasil, mas, como são encontrados em praticamente todos os animais próximos aos humanos e com freqüência sofrem recombinação com essas cepas animais, podemos aceitar que os rotavírus sejam extremamente antigos e tenham chegado ao Brasil no início da colonização européia. Como sofrem mudanças freqüentes, os rotavírus, assim como os vírus da influenza, podem ser considerados também 'eternos emergentes', ainda que a velocidade dessas modificações seja inferior à verificada com os vírus da influenza.

Em 2006, foi iniciada a vacinação universal de lactentes contra os rotavírus, o que deve resultar na redução do número e da intensidade dos surtos, assim como uma significativa redução dos óbitos. O surgimento de variantes não preveníveis pelas vacinas disponíveis é uma possibilidade concreta. 


\section{Aids, hepatites E OUtras Viroses de TRANSMISSÃO PARENTERAL E/OU SEXUAL}

Dificilmente, um grupo de doenças teve tamanho impacto tanto em saúde pública e na prática médica quanto no comportamento social. O surgimento da Aids e a descoberta de diferentes vírus de transmissão por transfusão sangüínea, procedimentos médicos e relacionamento sexual nas últimas décadas do século XX podem ser considerados um dos eventos marcantes do século passado.

A transfusão de sangue e seus derivados foi um dos grandes avanços da medicina na segunda metade do século XX. Esses avanços permitiram a realização de cirurgias cada vez mais complexas e possibilitaram a sobrevida de quadros graves, como traumas, queimaduras, neoplasias e outros. A purificação de componentes do sangue permitiu o tratamento de doenças graves como a hemofilia, mas trouxe também alguns riscos inerentes ao procedimento.

Neste grupo de vírus de transmissão parenteral e sexual estão o HIV, o vírus da hepatite B, o vírus da hepatite C, o citomegalovírus, o parvovírus humano B19 e outros menos conhecidos e de importância bem menor, como o vírus G.

\section{HIV (Aids)}

Os primeiros casos de Aids foram identificados no Brasil em 1982, no estado de São Paulo. Considerando o longo tempo entre a infecção e as manifestações clínicas, é razoável aceitar que o vírus já estivesse circulando anos antes, o que é corroborado pela ocorrência de casos em que a infecção foi adquirida por transfusão sangüínea anos antes de 1982. Qual teria sido a rota 
de introdução do HIV é um exercício especulativo. As evidências atuais mostram que o HIV surgiu na África, possivelmente pouco antes da Segunda Guerra Mundial, talvez na década de 1930, mas sua disseminação teria se dado apenas décadas depois, já na segunda metade do século passado, chegando ao Brasil através dos Estados Unidos.

O HIV é geneticamente semelhante a um vírus de macacos, o vírus da imunodeficiência símia (SIV), encontrado em algumas espécies de macacos africanos. Pela 'distância' genética entre os dois vírus, SIV e HIV-1, é possível aceitar que a diferenciação entre os dois tenha ocorrido em algum momento por volta das décadas de 1920 ou 1930, quando o SIV teria feito um salto de espécies, isto é, passado de uma espécie para outra - no caso, de macacos, possivelmente chimpanzés, para humanos. A carne de macaco é há muito tempo considerada uma iguaria por determinadas sociedades africanas e sua caça é comum. A contaminação humana poderia ter facilmente ocorrido quando da retirada da pele e preparação do chimpanzé para ser comido. Em macacos, o SIV é um vírus que quase não causa doença. Possivelmente, as infecções humanas iniciais também fossem inaparentes, benignas, tal como as infecções pelo HIV-2, um vírus muito similar ao HIV-1, o vírus da Aids, mas muito menos virulento. O HIV-2 também deriva do SIV - acredita-se que através de um processo idêntico, mas independente.

A evolução do HIV-1 de um vírus pouco virulento para um vírus bastante virulento teria ocorrido na segunda metade do século $\mathrm{XX}$, quando vários determinantes parecem ter contribuído para tanto. O processo de descolonização na África levou a profundas mudanças, entre elas a urbanização e migrações, o que aproximou diferentes etnias e populações antes isoladas ou 
com pouco contato entre si. Isso teria possibilitado uma transmissão mais intensa do HIV-1, permitindo sua disseminação rápida e a sustentabilidade das mutações que levaram à sua maior virulência.

A história da saúde pública da segunda metade do século $\mathrm{XX}$ pode ser dividida em dois períodos, um antes e outro depois do surgimento da Aids. O impacto do HIV na prática da saúde pública e mesmo em diferentes aspectos da sociedade foi, e ainda é, significativo.

Dados do Ministério da Saúde brasileiro indicam que, desde a notificação do primeiro caso (no início da década de 1980) até o ano de 2003, ocorreram 348.520 casos notificados, sendo a maior parte na região Sudeste. No início da epidemia, a doença acometia, principalmente, indivíduos do sexo masculino, homossexuais, hemofílicos e outros grupos de pacientes politransfundidos e usuários de drogas endovenosas, sobretudo de níveis socioeconômicos mais elevados, e habitantes de áreas metropolitanas de São Paulo e do Rio de Janeiro. A partir da década de 1990, principalmente após sua segunda metade, passou-se a observar uma ampliação geográfica das áreas de ocorrência, levando a uma 'interiorização' da epidemia. Somese a isso um significativo aumento da incidência da doença em heterossexuais e, conseqüentemente, em mulheres e recémnascidos. Tendo em vista o incremento da qualidade de sangue e hemoderivados, a transmissão do HIV por meio de transfusão sangüínea tornou-se um acontecimento esporádico, quase incidental.

A adoção de políticas de redução de danos focando, sobretudo, usuários de drogas endovenosas, uma ampla distribuição de preservativos, testagem sorológica e acompanhamento 
pré-natal vêm sendo importantes instrumentos que levaram à desaceleração da epidemia.

A partir de 1996, o Programa Nacional de Doenças Sexualmente Transmissíveis (DST) e Aids do Ministério da Saúde, através da disponibilização de recursos para diagnóstico, monitoramento da infecção (carga viral) e imunológico (contagem das células de defesa, linfócitos T CD4+) e, principalmente, pela distribuição universal de medicamentos anti-retrovirais proporcionou significativa redução na morbi-mortalidade associada à Aids. Atualmente, o modelo brasileiro de assistência ao indivíduo portador do vírus HIV/Aids é referência para muitos países do hemisfério Sul.

Com a introdução do 'coquetel', em que três ou mais drogas com atividade contra o vírus HIV passaram a ser utilizadas pelo indivíduo com significativa queda do status imunitário, foi possível o controle da replicação, a redução da carga viral e, conseqüentemente, a restituição do sistema imunológico (com elevação da contagem das células primariamente 'destruídas' pelo vírus, os linfócitos T CD4). Com isso, as chamadas infecções oportunísticas - as quais, quando não causavam a morte, muitas vezes levavam à incapacidade física e mental - foram sendo controladas.

Doenças como neurotoxoplasmose, citomegalovirose, pneumocistose, infecções fúngicas (criptococose, histoplasmose), micobacterioses atípicas e neoplasias - sendo o sarcoma de Kaposi, associado à infecção pelo herpes vírus 8, um paradigma em relação à Aids - passaram a se restringir aos casos em que a terapêutica anti-retroviral era iniciada tardiamente ou não era utilizada pelo paciente, por algum motivo que não fosse a falta de acesso. 
Hepatite B e D

Difícil comprovar a origem do vírus da hepatite $B$. Possivelmente, esta seja uma das poucas viroses com importância em saúde pública que já teria existido antes da chegada dos europeus. Diversos grupos étnicos autóctones da América apresentam elevada prevalência de infecção pelo vírus da hepatite B, incluídas aí diversas etnias da Amazônia.

A presença desses vírus nas populações indígenas da Amazônia, assim como em outras populações autóctones da América, do Alasca ao Peru, sugere que a introdução dos vírus da hepatite $\mathrm{B}$ e $\mathrm{D}$ teria se dado quando das migrações humanas da Ásia pelo estreito de Behring.

Independentemente dessa via, o vírus da hepatite B foi introduzido também pelos migrantes europeus, particularmente italianos e, em menor proporção, orientais. Ainda hoje se detecta uma maior prevalência do vírus em áreas de colonização italiana no Espírito Santo, no Rio Grande do Sul, em Santa Catarina e no Paraná.

Foi apenas em 1968 que o vírus da hepatite B pôde ser identificado. O vírus - ou melhor, a partícula viral delta - é um agente incompleto, não podendo se reproduzir na ausência do vírus da hepatite B.

Hepatite D (ou delta)

A OMS estima que existam cerca de dez milhões de pessoas infectadas em todo o mundo. Há dois padrões epidemiológicos da infecção pelo vírus da hepatite D: nos países da bacia do Mediterrâneo, o vírus é endêmico em portadores do vírus da hepatite B (esse padrão pode ser encontrado também na bacia Amazônica, particularmente em populações nativas); e na Europa 
não mediterrânea e na América do Norte, assim como em muitos outros países (inclusive no Brasil), pode ser encontrado em usuários de drogas injetáveis.

A transmissão do vírus da hepatite $\mathrm{D}$ ocorre principalmente por via parenteral e apresenta os mesmos mecanismos de transmissão do vírus da hepatite B. Nas áreas endêmicas da América do Sul, na Amazônia brasileira e venezuelana, a transmissão do vírus da hepatite $\mathrm{D}$ parece ocorrer por exposição inaparente, principalmente relacionada com pequenas lesões de pele através das mucosas.

A co-infecção pelo vírus da hepatite $\mathrm{D}$, seja em pessoas já infectadas pelo vírus da hepatite B ou por infecção simultânea, pode resultar em duas formas de doença grave: hepatite fulminante, com rápida evolução para falência hepática, com hemorragias; e hepatite crônica, com evolução para a cirrose e insuficiência hepática no espaço de poucos anos.

A hepatite fulminante foi muitas vezes confundida com outras doenças, entre elas a febre amarela. Essa forma, relativamente comum na Amazônia, recebeu a designação de febre negra de Lábrea, cuja etiologia só foi conhecida a partir da década de 1980, com a disponibilidade de meios laboratoriais para identificar o vírus da hepatite D. A febre de Lábrea é muito semelhante à hepatite fulminante, também pelo vírus $\mathrm{D}$, verificada na África Central, à febre de Bangui e à hepatite de Santa Marta, também pelo vírus $\mathrm{D}$, descrita no norte da Colômbia. Tanto a hepatite de Santa Marta como a febre negra de Lábrea puderam ser identificadas desde a década de 1930, sugerindo que a presença dos vírus da hepatite B e D são antigos ou mesmo autóctones, uma vez que são encontrados em diversas etnias indígenas da Amazônia brasileira e venezuelana. 
Hepatite C

No caso do vírus da hepatite C (VHC), também há dificuldade para determinar precisamente se é de fato emergente ou apenas a percepção de sua existência fez com que ele hoje seja considerado, juntamente com a Aids, um dos mais sérios problemas de saúde pública do mundo atual.

A hepatite pelo vírus C já foi citada como 'a próxima Aids', o que não deixa de ter um fundo de verdade, uma vez que a disseminação dessa doença, com seu potencial de causar doença crônica e câncer, se deu por todo o mundo, sendo que os países em desenvolvimento pagam um tributo mais elevado.

Diferentemente do vírus da hepatite $\mathrm{B}$, que tem na transmissão sexual uma das principais vias de disseminação, o vírus da hepatite $C$ se dissemina, praticamente, apenas pela via parenteral. Ainda que sua transmissão sexual possa ocorrer, a importância desta para a disseminação do vírus ainda é questão aberta.

Depois da identificação dos vírus das hepatites $\mathrm{A}$ e B na segunda metade do século XX, foi reconhecida uma quantidade significativa de casos de hepatite que não podiam ser atribuídos nem ao vírus da hepatite A, nem ao da hepatite B. Esses casos foram designados como sendo hepatite não-A não-B. Somente no início da década de 1990 foi identificado o vírus da hepatite C, agente etiológico da imensa maioria dos casos de hepatite não-A não-B, particularmente daqueles adquiridos por via parenteral.

O vírus da hepatite C é um vírus RNA da família Flaviviridae, com genoma em fita simples de polaridade positiva medindo 9,7 kilobases de comprimento. Na poliproteína, com uma longa fase de leitura aberta, ORF (open reading frame), distinguem-se as proteínas estruturais: core, E1 e E2 e as não-estruturais ou NS (1 a 5), estas últimas responsáveis pela replicação viral. 
A análise filogenética das seqüências genômicas permitiu a caracterização de seis genótipos (1 a 6), que são subdivididos em grupos a, b, c etc. Os genótipos 1 a 3 são encontrados no Brasil, assim como no restante das Américas, sendo o 1 o mais comum. Os demais genótipos são mais freqüentes na Ásia. Dentro de um mesmo genótipo e subtipo, podemos ainda ter variações do vírus da hepatite $\mathrm{C}$, denominadas quasispecies. Isso é possível devido à replicação imperfeita do vírus, com o surgimento de pequenas e constantes mutações. A maior ou menor diversidade das quasispecies parece estar relacionada com a pressão imunológica, já que costuma ser pequena nas fases iniciais da doença, com aminotransferases normais, sendo de alta heterogeneidade nos casos de doença hepática mais avançada e/ou baixa resposta terapêutica.

O surgimento das quasispecies, uma característica em comum do vírus da hepatite C e do HIV, faz deles 'eternos emergentes', uma vez que o surgimento de variantes é quase um contínuo, dificultando o desenvolvimento de vacinas e drogas terapêuticas.

A grande dificuldade de estudo da hepatite $\mathrm{C}$ reside no fato de ser o seu vírus um agente exclusivamente humano, não havendo animal de experimentação ou meios de cultura que se adaptem à pesquisa, exceto o chimpanzé, de custos proibitivos. Nas poucas investigações experimentais recentes, estudos demonstram que chimpanzés se reinfectam com vírus homólogos e heterólogos, mesmo na presença de anticorpos neutralizantes. Ratos transgênicos que conseguem expressar a proteína do core desenvolveram esteatose hepática no início da infecção pelo vírus da hepatite $\mathrm{C}$, evoluindo posteriormente para carcinoma hepatocelular. Já as proteínas E1/E2, nesse mesmo modelo animal, provocaram o desenvolvimento de manifestações extra- 
hepáticas, em glândulas salivares e lacrimais, semelhantes à síndrome de Sjögren.

$\mathrm{O}$ vírus da hepatite $\mathrm{C}$ é muito grave, pois ele não determina apenas uma hepatite. É o agente causal de mais de $90 \%$ das hepatites pós-transfusionais, antes da introdução de programas de triagem do sangue doado. Assim, todas as pessoas que receberam transfusão de sangue ou de seus derivados até o início da década de 1990, com ou sem história de hepatite póstransfusional, devem ser avaliadas para provável contaminação com o vírus da hepatite C.

No Brasil, a partir de 1993, há a obrigatoriedade dos testes sorológicos (antiVHC) em candidatos a doadores de sangue. Assim, a hepatite pós-transfusional tornou-se rara, mas outros meios, parenterais ou não, continuam a disseminar a doença. Além dos produtos do sangue, agulhas e seringas contaminadas ou mesmo as drogas de uso inalatório, com o uso de espelhos e canudos contaminados, são vias importantes.

Outras formas parenterais de contaminação são os procedimentos médicos e odontológicos, além de realização de tatuagem ou sessões de acupuntura. Portanto, qualquer material cortante ou perfurante pode ser veículo transmissor do vírus de uma pessoa para outra, como o alicate da manicura, a lâmina do barbeiro ou mesmo a escova de dentes compartilhada por cônjuges ou filhos. Entre os casos eventualmente rotulados como 'esporádicos' - que não têm como causa a transfusão de sangue ou o uso de drogas ilícitas -, houve uma porcentagem significativa de pacientes com cirurgias prévias e/ou atendimentos médicos de urgência em prontos-socorros. Uma grande fonte médica de transmissão da hepatite $\mathrm{C}$ foram as máquinas de hemodiálise. Mesmo nos dias atuais, com normas de segurança bastante rígidas, 
ocorrem surtos localizados de transmissão deste vírus em serviços de hemodiálise.

Entre as formas não-parenterais de transmissão da hepatite C, torna-se importante ressaltarmos a possibilidade da transmissão sexual. Embora pouco eficiente, deve-se examinar e alertar o parceiro sexual, particularmente nos indivíduos promíscuos, para os quais é mandatório o uso de preservativos. Aos casais monogâmicos de longa data, sem doenças sexualmente transmissíveis, é facultativo o uso continuado de preservativos, sendo possível a gravidez.

Os índices de contaminação do parceiro sexual variam de 6 a 10\%. A disseminação intrafamiliar também é possível, devido provavelmente ao uso comum de materiais cortantes ou à exposição de ferimentos abertos. A transmissão materno-fetal, tão importante na hepatite $\mathrm{B}$, é pouco significativa na hepatite $\mathrm{C}$, podendo ocorrer no momento do parto, quando o feto se expõe ao sangue da mãe. Diferentemente da hepatite $\mathrm{B}$, não existe profilaxia para o recém-nascido, que terá o antiVHC da mãe nos primeiros seis a 12 meses de vida. Em vários estudos realizados, os anticorpos costumam desaparecer nesse período, podendo haver verdadeira contaminação com permanência do RNA-VHC em raros casos, principalmente quando da coinfecção do vírus da hepatite C e o HIV.

O tempo de incubação da hepatite $\mathrm{C}$ é variável, de um a treze meses, com média de oito. Logo após a contaminação, o melhor marcador e único disponível até o presente é a determinação do RNA-VHC, já que os anticorpos surgem apenas dentro de quatro a vinte semanas após o contágio. Como as formas anictéricas da hepatite $\mathrm{C}$ correspondem a cerca de $70 \%$ dos casos, os indivíduos contaminados evoluem para a cronicidade totalmente 
assintomáticos, sem terem conhecimento da presença do antiVHC ou mesmo do aumento de enzimas hepáticas, como a ALT.

Os mecanismos responsáveis pela persistência da infecção pelo vírus da hepatite $\mathrm{C}$ não foram ainda elucidados. A existência de quasiespecies e a grande capacidade mutagênica do vírus propiciam o constante escape à intensa resposta imunológica desenvolvida pelo hospedeiro. Assim, cerca de 85\% dos indivíduos infectados evoluem para a forma crônica. A infecção crônica pelo vírus da hepatite $C$, além de evoluir lentamente em anos ou décadas, costuma apresentar um amplo espectro clínico, desde formas assintomáticas com enzimas normais até a hepatite crônica intensamente ativa, cirrose e hepatocarcinoma.

A progressão da lesão hepática, da hepatite crônica para a cirrose, pode ainda relacionar-se a fatores do hospedeiro, ou seja, sexo, idade, uso de álcool ou concomitância com outros vírus. O mais importante dos fatores do hospedeiro, entretanto, parece ser o seu estado imunológico. Assim, uma resposta imunológica vigorosa pode eliminar o vírus da hepatite $\mathrm{C} \mathrm{em}$ $15 \%$ dos indivíduos que entram em contato com ele, enquanto, em pacientes crônicos ou imunossuprimidos, a doença evolui mais rapidamente para cirrose e hepatocarcinoma quando comparada aos imunocompetentes. Portanto, após transplantes hepáticos por cirrose com vírus da hepatite $\mathrm{C}$, recomenda-se que a terapia imunossupressiva seja a menor possível. Na coinfecção VHC-HIV, a progressão da doença revela-se mais rápida, se comparada aos pacientes HIV negativos, de forma semelhante ao que ocorre na co-infecção com o vírus da hepatite B.

Fatores hormonais e genéticos devem estar implicados na patogênese da hepatite pelo vírus da hepatite $\mathrm{C}$, sendo aceito que a doença costuma progredir mais rapidamente no sexo 
masculino. A idade do paciente ao adquirir a infecção também se mostra relevante, havendo pior prognóstico naqueles com idade superior a 40 anos. Outro importante fator, variável independentemente no prognóstico evolutivo da fibrose hepática, é o consumo alcoólico. Os mecanismos, não bem elucidados, envolvem aumento de carga viral induzida pelo álcool, assim como lesões imunomediadas e hepatotóxicas.

\section{HTLV-I e HTLV-II}

A sigla HTLV deriva do inglês Human T-cell Lymphoma Virus. Estes vírus pertencem à família Retroviridae, a mesma do HIV, o agente da Aids (inicialmente o HIV foi designado como HTLV-III). Os retrovírus são RNA vírus muito pequenos. Relativamente ubíquos entre animais, estes dois retrovírus são comumente discutidos de maneira associada pela relativa dificuldade em distinguir os anticorpos induzidos por um e outro.

O HTLV-I causa a leucemia/linfoma de células T do adulto (LLTA), a paraparesia espástica tropical/mielopatia associada ao HTLV (TSP/HAM), uveíte associada ao HTLV (HAU) e anormalidades dermatológicas e imunológicas. O HTLV-II não se mostrou associado a qualquer doença até o momento. $\mathrm{O}$ diagnóstico é feito com testes de triagem (Elisa, aglutinação) e confirmatórios (Western Blot, PCR). Estes vírus são transmitidos pelo sangue e por agulhas contaminadas, através de relações sexuais e de mãe para filho, especialmente pelo aleitamento materno. Medidas de prevenção devem focalizar a orientação de doadores soropositivos, mães infectadas e usuários de drogas intravenosas.

A infecção pelo HTLV-I/II caracteriza-se por: agrupamento da infecção em áreas geográficas definidas no mundo; variação 
espacial das taxas de soroprevalência dentro de áreas de prevalência reconhecidamente elevadas; aumento da soroprevalência com a idade (efeito da idade, efeito de coorte, soroconversão tardia) e soroprevalência mais elevada em mulheres, mais acentuada após os 40 anos.

O HTLV-I é endêmico no Japão, no Caribe, na África, na América do Sul e nas ilhas da Melanésia. Estima-se que 15 a 20 milhões de pessoas estão infectadas pelo HTLV-I no mundo. No Brasil, ele está presente em todos os estados onde foi pesquisado, com prevalências variadas. Estimativas baseadas nas prevalências conhecidas apontam para aproximadamente 2,5 milhões de pessoas infectadas pelo HTLV-I, o que torna o Brasil o país com o maior número absoluto de casos. O HTLV-II também está presente no Brasil, sendo significativa a sua prevalência entre populações indígenas brasileiras.

Na infância, a soropositividade para o HTLV-I é muito baixa e aumenta a partir da adolescência e início da idade adulta. Esse aumento é mais acentuado em mulheres do que em homens: nelas o aumento continua após os 40 anos, enquanto neles atinge um platô depois desta idade. A explicação mais provável para essa diferença é a transmissão por via sexual mais eficiente do homem para a mulher e as transfusões sangüíneas mais freqüentes em mulheres. A inclinação da curva e a taxa máxima de prevalência alcançada dependerão da região e da população estudada, mas o tipo de curva descrita parece reproduzir-se em todos os locais.

Existe controvérsia com relação à origem dos vírus. Várias pesquisas têm sido feitas tentando explicar sua origem através do estudo da heterogeneidade molecular entre os isolados virais de várias regiões. Retrovírus relacionados ao HTLV foram isolados de diversos primatas, na África e na Ásia, sugerindo a 
possibilidade de transmissão enzoótica ao homem. Aparentemente, o HTLV veio para a América com as migrações vindas da Ásia há cerca de 12 mil anos. Foram identificados no Caribe agrupamentos compatíveis com origem africana, através do tráfico de escravos. No Japão, os estudos sugerem que o vírus foi introduzido pelas sucessivas migrações humanas em épocas remotas (2.300 a dez mil anos atrás).

Grande parte dos trabalhos sobre a epidemiologia do HTLV-I consiste em estudos de soroprevalência em doadores de sangue, pacientes com LLTA, TSP/HAM e usuários de drogas intravenosas (UDIs). A presença da infecção sem resposta de anticorpos parece ser evento raro, embora pouco estudado. Ainda hoje, a utilização de metodologia diagnóstica muito variada, tanto para triagem quanto para confirmação, dificulta a comparação entre estudos realizados em diferentes momentos e áreas do mundo.

São associadas associadas ao HTLV-I as seguintes doenças:

- Complexo neurológico associado ao HTLV - uma grande variedade de manifestações neurológicas tem sido descrita em indivíduos infectados pelo HTLV-I (Atkinson, 2007; Figueiredo, 2007). Embora a mais comum seja a paraparesia espástica tropical/mielopatia associada ao HTLV-I (TSP/HAM), em um número expressivo de casos o que se observa é a associação de várias manifestações além da mielopatia propriamente dita em um mesmo paciente. Daí o termo 'complexo neurológico' associado ao HTLV-I.

As síndromes que fazem parte do complexo neurológico associado ao HTLV-I têm um substrato patogênico distinto da LLTA. Ainda não são conhecidos com exatidão os mecanismos pelos quais um portador assintomático do vírus evolui para a 
doença, ou seja, os determinantes da história natural da infecção. Sabe-se que pacientes com doença neurológica exibem uma carga proviral maior do que os portadores assintomáticos e pacientes com LLTA. A carga proviral parece ser determinada por alelos contidos no sistema HLA. Deste modo, determinantes genéticos estariam associados à transição de assintomático para doente.

- Leucemia/linfoma de células T do adulto - a LLTA é uma entidade clínico-patológica distinta devido à sua associação etiológica com o HTLV-I. As evidências que demonstraram o papel etiológico do HTLV-I nesta doença são: 1) presença de LLTA em região endêmica para HTLV-I; 2) todos os pacientes com LLTA apresentam anticorpos para HTLV-I; 3) a integração monoclonal do DNA proviral nas células leucêmicas dos pacientes, confirmando que a LLTA surgiu da transformação maligna de uma célula previamente infectada com HTLV-I. A maior incidência de LLTA ocorre, em geral, após a terceira década de vida, tendo sua expressão máxima em indivíduos de 40 a 60 anos de idade.

Nas regiões reconhecidas como áreas endêmicas para a infecção pelo HTLV-I, foram adotados testes laboratoriais e critérios de classificação clínica de LLTA. Portanto, para o diagnóstico de LLTA é necessário que o paciente apresente características que preencham os critérios de diagnóstico, tais como: anticorpos anti-HTLV-I, presença de células malignas linfóides da linhagem T (CD2, CD3, CD4+ e CD25+) e comprovação da integração do HTLV-I proviral monoclonal.

As formas clínicas desta doença são classificadas em quatro grupos: forma aguda, crônica, linfomatosa e smoldering (McLaughlin-Drubin \& Munger, 2008; Van Der Hoek, 2007). Em geral, um estágio intermediário entre o portador sadio e o 
doente com monoclonalidade passa a ser denominada como LLTA do tipo smoldering. Esta forma pode evoluir para as formas crônica ou aguda em tempo variado entre dez a quinze anos.

\section{OUTRAS VIROSES}

Raiva

Dificilmente a raiva pode ser considerada uma doença emergente. Reconhecida há pelo menos quatro mil anos - sua descrição mais antiga data do século II a.C. na Mesopotâmia -, é encontrada em praticamente todo o mundo, tendo se disseminado com as migrações humanas ao longo do tempo. A raiva pode ocorrer em animais silvestres em todos os continentes, com exceção da Oceania. A OMS estima que ocorram de 25 mil a 90 mil casos com óbitos anualmente em todo o mundo, a maioria no Sudeste Asiático, na África e na China.

$O$ vírus da raiva pertence ao gênero Lyssavirus, da famíla Rhabdoviridae, e é encontrado em diversos animais, particularmente canídeos (raposa, cão, lobo, chacal), mas praticamente todos os mamíferos são suscetíveis à infecção pelo vírus da doença. Do ponto de vista de saúde pública, o cão é o principal transmissor da raiva, notadamente nas cidades e áreas rurais. O morcego pode ser transmissor da raiva, geralmente nas áreas de mata, mas também nas cidades.

Hoje sabemos que o vírus da raiva tem pelo menos sete variantes (genótipos), quatro das quais capazes de causar doença humana, semelhante à encefalite da raiva. São eles: vírus da raiva, Lagos, Mokola, Duvenhage, Lissavírus europeu 1, Lissavírus europeu 2 e Lissavírus australiano de morcegos.

Os lissavírus europeus e australiano são encontrados em morcegos e podem causar doença humana, ainda que rara. Os 
genótipos Lagos, Mokola e Duvenhage, todos africanos, não foram descritos causando doença humana, sendo encontrados em morcegos frugívoros (Lagos), em pequenos mamíferos (Mokola) e em morcegos insetívoros (Duvenhage). Recentemente, outras quatro variantes foram descritas: vírus de morcegos do Cáucaso Ocidental, vírus Aravan, vírus Khujand e vírus Irkut.

A raiva teria sido introduzida nas Américas com a importação de animais durante o período colonial. Se a raiva de morcegos já existia anteriormente, é uma questão aberta. No Brasil, a raiva transmitida pelo cão ainda é um problema, particularmente nas regiões Norte e Nordeste, mas a vacinação sistemática de cães e gatos, feita anualmente, vem reduzindo o número de casos humanos.

A raiva de morcegos permanece como um problema, tanto econômico, por acometer o gado bovino, como de saúde pública, por representar um risco permanente de transmissão a humanos. $\mathrm{Na}$ região Amazônica, a ocorrência de ataques de morcegos hematófagos a humanos é um problema emergente, não somente no Brasil, mas também na Colômbia, no Equador e no Peru. Aparentemente, o vírus da raiva teria se disseminado há pouco tempo entre os morcegos da Amazônia, uma vez que ataques de morcegos são relatados há muito tempo, mas somente nos últimos anos é que foram identificados casos humanos de raiva transmitida por esses animais.

Morcegos são animais cujo equilíbrio ecológico é facilmente perturbado por alterações do ambiente com redução de suas fontes naturais de alimentos, levando-os a se aproximar dos humanos e a procurar presas diferentes. Isso explica a crescente identificação de vírus emergentes tendo morcegos como reservatório e vetor, desde os vírus Ebola e Marburg, os 
coronavírus causadores da SARS, os vírus Nipah e Hendra e os próprios lissavírus.

\section{Hepatite E}

Ainda que os estudos realizados até o momento mostrem que a presença do vírus da hepatite $\mathrm{E}$ é rara, ao contrário do que ocorre no México, na África e na Ásia, é interessante entender o contexto desse vírus em nosso meio, uma vez que o seu reconhecimento vem mudando constantemente em diversos países.

O vírus da hepatite E causa uma hepatite autolimitada, geralmente benigna, mas particularmente grave em gestantes no segundo e terceiro trimestre de gestação. Reconhecido como causa de hepatite somente a partir de 1980, o vírus da hepatite E (VHE) tem variantes, uma das quais parece ser exclusivamente humana, transmitida por contato pessoal, pela água e por alimentos contaminados, muito à semelhança do vírus da hepatite A. Diferentemente desse, o vírus da hepatite E apresenta variantes, que também podem infectar humanos e causar hepatite, mas que tem animais como reservatórios, entre eles suínos, bovinos, primatas não-humanos, caprinos, ovinos e roedores.

$\mathrm{O}$ vírus da hepatite $\mathrm{E}$ se dissemina nas mesmas condições ambientais que as do vírus da hepatite A: saneamento deficiente e clima quente e úmido. Porém, apesar da ainda elevada prevalência da infecção pelo vírus da hepatite A em praticamente todo o país, epidemias ou surtos de hepatite $\mathrm{E}$ nunca foram detectados no Brasil. Não obstante, um número crescente de estudos publicados vem mostrando que a presença do vírus da hepatite $\mathrm{E}$ é relativamente comum, tanto em humanos como em animais, assim como em tratadores de animais, particularmente porcos. Essa situação já foi descrita nos Estados Unidos e na Europa. 
No momento, a importância do vírus da hepatite E em saúde pública é pequena. No entanto, a exemplo do que vem ocorrendo na Europa e nos Estados Unidos, a percepção da sua importância pode mudar em futuro próximo. A hepatite $\mathrm{E}$ não causa doença crônica, mas pode levar ao óbito por falência hepática. Não existe vacina ou tratamento específico, porém há vacinas em desenvolvimento. 



\section{$6 \mid$ Vírus, Especulações e Perspectivas}

O contexto epidemiológico dos vírus é continuamente modificado. Dada a facilidade de transmissão da maioria desses agentes, o processo de globalização e a elevada taxa de mutação de muitos deles, possivelmente a situação descrita aqui se modifique significativamente em pouco tempo. O constante aperfeiçoamento da tecnologia diagnóstica também permitirá a identificação de novos vírus.

Como assinalado, o desenvolvimento da biologia molecular e da tecnologia a ela associada permitiu uma verdadeira explosão do conhecimento a respeito dos vírus. Assim, é de se esperar que nos próximos anos o papel desempenhado por estes na ocorrência de doenças sofra mudanças substanciais, mostrando sua participação em doenças até então tidas como não infecciosas.

A acelerada transformação da natureza pelas sociedades humanas na sua busca para gerar riquezas é hoje, e continuará sendo, um determinante importante da emergência das viroses. Essa pressão ecológica se faz sentir de maneira particular sobre os morcegos, que cada vez mais assumem um papel importante como reservatórios e vetores de vírus. Morcegos, sem dúvida, sempre foram reservatórios de vírus. No entanto, o equilíbrio ecológico dessas espécies é extremamente delicado e a retirada de suas fontes naturais de alimento, com o rápido desmatamento verificado em diferentes partes do mundo, traz os morcegos 
cada vez mais próximos dos agrupamentos humanos, permitindo a transmissão de diferentes vírus.

Exemplos claros do papel dos morcegos são não só a transmissão da raiva, como o surgimento de vírus como Nipah e Hendra, Ebola e Marburg e o coronavírus causador da SARS.

\section{VíRUS INEXISTENTES NO BRASIL, MAS COM RISCO DE INTRODUÇÃO}

No presente, pelo menos quatro vírus - três dos quais amplamente disseminados globalmente - ainda não atingiram o Brasil, mas nada impede que sejam introduzidos em futuro próximo. São eles: Vírus do Nilo Ocidental, Chikungunya, Dengue sorotipo 4 e Influenza pandêmica.

\section{Vírus do Nilo Ocidental}

O vírus do Nilo Ocidental, originário da África, onde foi descrito inicialmente em Uganda na década de 1930, já se disseminou para o Oriente Médio, a Europa (particularmente nos países próximos ao Mediterrâneo), os Estados Unidos, o Canadá e o México e se expande em direção sul, acometendo alguns países do Caribe e da América Central (Porto Rico, República Dominicana, Jamaica, Guadalupe e El Salvador). Tratase de um flavivírus que causa um quadro febril relativamente benigno, mas que pode ser grave em pessoas de idade avançada, causando encefalite, muitas vezes fatal.

Transmitido por mosquitos do gênero Culex (o pernilongo comum), acomete pássaros - responsáveis por sua disseminação à longa distância - e usualmente acomete cavalos antes de atingir os humanos. Pode ser transmitido também por transfusão sangüínea. Nos Estados Unidos e no Canadá, onde a doença se 
tornou relativamente comum no verão, já se verificaram diversos casos por transmissão sangüínea e através de órgãos transplantados.

A possibilidade de introdução do vírus do Nilo Ocidental no Brasil é concreta. Resta saber se a exposição prévia à dengue (outro flavivírus), hoje bastante elevada na maioria das cidades brasileiras, irá agir como um freio para a disseminação do vírus. A imunidade à dengue não confere imunidade ao vírus do Nilo Ocidental, mas pode ser suficiente para reduzir a intensidade e a duração da viremia, dificultando a transmissão.

Recentemente foi notificada a existência de um cavalo infectado pelo vírus do Nilo Ocidental na Argentina. Porém, depois disso, não se verificou nenhum outro caso.

\section{Chikungunya}

Outro vírus de expansão recente é o chikungunya, que causa uma doença muito semelhante à dengue, mas menos severa. Transmitido por mosquitos, particularmente o Aedes albopictus, provocou recentemente uma epidemia em ilhas do oceano Índico que se estendeu para a Índia e chegou a provocar casos autóctones na Itália, no final do verão de 2007.

$\mathrm{O} A$. albopictus é amplamente disseminado por quase todo o mundo, inclusive no Brasil. Como a virose é relativamente benigna, a sua introdução por viajantes é bastante provável. Dadas as condições climáticas brasileiras, o vírus se disseminaria com relativa facilidade.

\section{Dengue sorotipo 4}

Além desses dois vírus, o Brasil está sob risco de introdução do sorotipo 4 do vírus da dengue, a única das quatro variantes do vírus que ainda não circula pelo país. Esta variante pode ser encontrada no norte da América do Sul, na América Central, no 
Caribe e na Ásia. Sua introdução, ainda que não venha a determinar uma doença 'nova', poderá causar grandes epidemias com formas graves de dengue.

A ocorrência de infecção pelo DEN-4 já foi detectada em Manaus (AM), ainda que em poucos casos. É de se esperar, portanto, que sua disseminação pelo restante do país se verifique nos próximos anos.

\section{Influenza pandêmica}

É importante separar a discussão da influenza em pandêmica e sazonal (discutida anteriormente), pois, ainda que se trate da mesma doença e do mesmo vírus, a dinâmica epidemiológica difere um pouco.

O termo pandemia, ainda que signifique uma epidemia que acomete vários continentes (ver Glossário), ao se discutir influenza, é reservado àquela causada por um vírus recentemente emergente, contra o qual a humanidade não apresenta imunidade, resultando numa pandemia de maior morbidade e mortalidade.

Pandemias de influenza vêm ocorrendo há muito tempo, com certeza desde o século XVI, possivelmente até antes. Não seria novidade, portanto, ocorrer uma nova. Por que, então, toda essa preocupação e, até, um certo alarme?

Esta é a primeira vez, graças aos avanços da ciência, que temos a possibilidade de acompanhar - e entender - o processo que antecede a eclosão de uma pandemia. Ainda que estas venham ocorrendo numa freqüência regular de três a cada século, nunca se compreenderam com clareza os seus determinantes. As pandemias eram percebidas quando já estavam em pleno curso.

Durante o século XX, houve três pandemias de gripe: em 1918, em 1957 e em 1968. Já se passaram, portanto, quarenta 
anos desde a última. Seria iminente uma outra? Possivelmente sim, ainda que nada aponte para o fato de que exista um intervalo de tempo máximo ou mínimo entre pandemias, nem que, necessariamente, uma nova pandemia venha a ocorrer. Cabe em saúde pública, porém, adotar o princípio da prudência: preparar para o pior cenário e esperar o melhor.

Ainda que pandemia, na sua definição mais estrita, seja uma epidemia de âmbito mundial, em influenza o termo ganha uma acepção mais ampla, uma vez que as epidemias anuais de gripe, mesmo sendo de âmbito mundial na maioria das vezes, não são denominadas pandemias. Uma epidemia de gripe, para ser considerada uma pandemia, deve ter abrangência mundial e, ao mesmo tempo, ter gravidade maior, geralmente por ser causada por um vírus contra o qual a humanidade não tenha imunidade prévia ou que apresente características de uma maior virulência.

Influenza e suas pandemias constituem assunto amplamente discutido na mídia, mas nunca é demais relembrar. Os vírus da influenza são comuns e amplamente disseminados, existindo em três grandes grupos, denominados A, B e C, mas apenas os dois primeiros são de interesse por causarem doença potencialmente grave em humanos. O vírus A é o responsável pelas pandemias; o B causa surtos e epidemias localizadas, ainda que possam ocasionar grande número de óbitos.

Onde houver vertebrados de sangue quente, sejam baleias, cavalos, porcos, aves ou humanos, lá estará o vírus da influenza A. Aves são, sem dúvida, os hospedeiros originais dos vírus da influenza. Nas aves aquáticas, circulam diferentes subtipos do vírus, mais de 15 , e essas aves, por muitas vezes serem migratórias, se encarregam de disseminar o vírus pelo mundo. Das aves aquáticas, os vírus acabam acometendo as aves domésticas, particularmente 
aquelas de interesse econômico, como galinhas, patos, perus, gansos e outras. Nas aves, os vírus são excretados tanto nas fezes como nas secreções respiratórias. Essa ampla circulação e a fácil transmissão resultam em circuitos simultâneos de circulação de vírus, à medida que se adaptam a esta ou aquela espécie.

Entre os vírus adaptados a humanos, hoje se encontram dois tipos principais do vírus da influenza A: H1N1 e H3N2. Eles circulam e causam as epidemias anuais que conhecemos bem. Essas epidemias, ainda que conhecidas, estão longe de ser benignas: a cada ano, durante a temporada da influenza (quase sempre no inverno), milhares de pessoas acabam adoecendo e muitas morrendo. Estima-se que apenas nos Estados Unidos morram, a cada ano, cerca de vinte mil a cinqüenta mil pessoas por influenza, a maioria idosos, mas também crianças e indivíduos com doenças crônicas.

Em todo o mundo, estimar um número de meio milhão de óbitos devido à influenza a cada ano não é um absurdo. Vejamos porque: somos 6,5 bilhões de habitantes e, anualmente, cerca de $10 \%$ da população mundial adoece de gripe. Isso nos dá um número estimado de 650 milhões de casos de influenza. Considerando a letalidade média da influenza como 0,1\%, teremos pouco mais de meio milhão de óbitos anuais. A razão do pequeno impacto desses óbitos na mídia e mesmo entre os profissionais da saúde é que estão concentrados nos dois extremos etários, lactentes e idosos, além de pessoas com doenças crônicas. Os óbitos não costumam ser fulminantes. Ao contrário, resultam de complicações, o que acaba obscurecendo o vínculo causal com a influenza.

Por que as epidemias se repetem anualmente? Isso se deve a uma característica importante dos vírus da influenza A, que 
sofrem mutações com grande facilidade e regularmente. Por isso, a cada ano (ou a cada dois ou três anos), os vírus circulantes sofrem pequenas modificações, que lhes confere maior ou menor capacidade de causar doença e também faz com que a imunidade desenvolvida aos vírus dos anos anteriores não seja completamente protetora. Essas mudanças de pequena monta ocorrem constantemente, mas não são suficientemente extensas para determinar uma pandemia.

Em momentos mais distantes entre si, esses vírus sofrem mudanças significativas, fazendo com que a imunidade desenvolvida aos vírus anteriormente não confira praticamente nenhuma proteção e, às vezes, lhes dá uma capacidade muito maior de causar doença grave do que o usual para um vírus da influenza. Assim foi em 1918, quando se acredita que um vírus aviário tenha se adaptado aos humanos passando a causar doença grave. Possivelmente também em 1957 e em 1968. Isso pode se dar diretamente, um 'salto de espécies', o vírus passando de aves para humanos e, lentamente, sofrendo mutações que lhe confiram a capacidade de transmissão direta entre humanos, dispensando as aves. Outra via indireta é o vírus passar de aves para suínos e nesses sofrer uma recombinação com vírus humanos, que infectam indiferentemente suínos e humanos, resultando num terceiro vírus adaptado à transmissão entre humanos e mantendo a virulência de seus ancestrais aviários.

A descrição anterior coincide exatamente com o que estamos assistindo desde Hong Kong, em 1997, até hoje na Turquia, passando por diversos países da Ásia. Em 1996, um novo vírus aviário, o H5N1, capaz de dizimar as aves de criação em horas, foi identificado e, em 1997, causou os primeiros casos humanos, 18 ao todo, levando a seis óbitos. 
A preocupação maior se dá pelo fato de que a prática vem coincidindo com a teoria e tem sido possível documentar todo o processo. $\mathrm{O}$ vírus aviário isolado dos pacientes na China, no final de 2005, difere do isolado dos pacientes do Vietnã, em 2003, prova cabal da constante mutação do vírus. É uma questão de oportunidade, simples como compreender que, quanto mais vezes atravessamos a rua, maior o risco de sermos atropelados; quanto maior o número de vírus se replicando, maior a probabilidade de ocorrerem mutações. É exatamente isso o que vem ocorrendo: a presença de aves e humanos infectados em número crescente na Turquia indica claramente que o vírus está com o caminho livre, seja através das aves migratórias, que o levaram da Ásia para a Turquia e Romênia, seja através das aves domésticas, presas fáceis da influenza aviária, capaz de dizimar um plantel de milhares de galinhas ou perus em um dia aproximadamente, ainda que não tenham sido detectadas mutações.

Porém, a incidência em humanos não é assustadora, ainda que a letalidade o seja. A OMS contabilizou, até 13 de novembro de 2007, 258 casos desde dezembro de 2003, com 163 óbitos, os mais recentes na Indonésia. Possivelmente a letalidade seja menor, pois a OMS registra apenas os casos confirmados laboratorialmente, o que induz a um viés de gravidade. Com exceção da Indonésia, onde a doença vêm ocorrendo em doses homeopáticas, mas continuadas, nos demais países parece ter havido um surto para depois se chegar a um aparente controle, sendo este surto claramente relacionado com outro correspondente em aves. Em vários países, como na Tailândia e na Turquia, os casos humanos parecem estar relacionados com o processo de eliminação das aves, em que não se tomaram os 
devidos cuidados para acabar com o risco de transmissão para a população local. Nos jornais e noticiários de televisão, foram freqüentes as cenas em que crianças brincavam lado a lado das equipes que eliminavam as aves.

Causa preocupação, no entanto, a confirmação recente de casos no Iraque, país devastado pela guerra e ainda com instabilidade social, militar e política (companheiras inseparáveis das epidemias). Da mesma maneira, o encontro do H5N1 em aves na África do Sul, ainda que uma variante menos patogênica, atesta a capacidade de disseminação desse vírus.

Parece claro, portanto, que não se trata mais de uma questão sobre se teremos uma pandemia, mas, sim, sobre quando ela acontecerá e com qual gravidade. $O$ vírus causador da pandemia será muito possivelmente um descendente direto do vírus aviário, H5N1, que terá adquirido uma capacidade que no momento não apresenta: transmissão direta de humano a humano. Assim, a preocupação não é com o momento atual, mas com o que dele advirá. Hoje, o cenário da pandemia está sendo preparado e os atores estão sendo ensaiados.

E o Brasil, como se situa nesse processo? Parece pouco provável que venhamos a viver uma situação semelhante à da Turquia, da China ou do Sudeste Asiático, com uma epidemia arrasadora em aves e poucos, mas graves, casos humanos. Estamos fora da rota das aves migratórias européias e asiáticas. A única outra maneira de introdução do vírus na sua versão aviária seria através do comércio de aves. O Brasil é hoje o maior exportador mundial de carne de frango. Exportamos, não importamos, o que diminui consideravelmente o risco. Somos importadores de matrizes, aves para manter o padrão genético dos plantéis comerciais. O risco aqui é mínimo, pois se trata de 
um comércio altamente sofisticado em termos de biossegurança. Cabe ficar atento para algum galo de briga importado ilegalmente da Tailândia, um ponto fraco na nossa segurança, principalmente por se esquivar de controles e não figurar em qualquer estatística oficial.

O nosso problema será quando a pandemia efetivamente começar em algum ponto do mundo, acredita-se que no sudeste da Ásia ou em algum lugar da China, a exemplo de outras pandemias recentes. A influenza humana é uma doença altamente contagiosa e seu período de maior transmissibilidade se dá exatamente durante a incubação, quando a ausência de sintomas impede o diagnóstico clínico da doença e o futuro paciente se sente bem o bastante para viajar livremente.

O número de viagens e viajantes apresenta uma tendência ao crescimento. Apenas as viagens de turismo internacional, não contando as demais, chegaram a 763 milhões em 2004, um crescimento anual de 6,5\%, se considerarmos que, em 1950 , foram 25 milhões. O movimento financeiro mundial do setor de viagens representou 625 bilhões de dólares americanos em 2004, significando que o número de viajantes é elevado. A estimativa é que, em 2020, cerca de 1,5 bilhão de turistas realizem viagens internacionais anualmente - hoje, cinqüenta milhões de viagens internacionais são realizadas por motivos comerciais e existem aproximadamente 120 milhões de refugiados e imigrantes ilegais em todo o mundo.

Não há sistema de quarentena ou controle em portos e aeroportos que impeçam a introdução da influenza, diferentemente da SARS. Nesta doença, é possível, através do uso sensato da quarentena e do isolamento, reduzir significativamente o risco de disseminação. 
Cabe aceitar, portanto, que, caso haja uma pandemia, esta chegará ao Brasil, talvez num momento próximo ao de outros países da América. Ainda assim, nós estamos numa posição favorecida, em que o risco da introdução da doença em aves é mínimo, e o risco de introdução da doença em humanos, quando e se ocorrer, é certo, mas se dará muito provavelmente depois da Europa e da Ásia. É de se prever, então, que tenhamos um tempo precioso para tomar as necessárias precauções.

As precauções estão sendo tomadas? Sim, o Brasil integra a lista de países que já contam com um plano inicial de contingência para o caso de a pandemia ocorrer. Esse plano segue as recomendações da OMS e, inclusive, o Ministério da Saúde já se posicionou para a compra de antivirais suficientes para nove milhões de tratamentos. Esse antivirais, segundo as recomendações mundiais, servirão para conter os surtos iniciais no momento em que uma vacina ainda não for disponível e para proteger alguns segmentos essenciais da população que apresentam um risco elevado de complicações da influenza. A finalidade de um plano é permitir a manutenção da normalidade social e econômica, reduzindo os casos e os óbitos, e não necessariamente impedir que a doença ocorra, pois isso seria utópico. Fazer com que uma eventual pandemia transcorra num período de tempo maior, desconcentrando os casos e permitindo que sejam tomadas as medidas necessárias, é o grande objetivo.

Quanto à vacina, dificilmente poderá ser fabricada antes da eclosão dos primeiros surtos da pandemia, uma vez que, neste momento, não conhecemos o vírus, pois ele simplesmente não existe. Como já foi dito, ele será, muito provavelmente, um descendente do atual H5N1, mas com características impossíveis de se prever. As vacinas em desenvolvimento, amplamente 
anunciadas, devem ser vistas como apenas um 'ensaio geral' para avaliar a capacidade dos produtores em desenvolver uma vacina no menor tempo possível. As vacinas contra a influenza utilizadas anualmente na rotina costumam levar cerca de cinco a seis meses para serem produzidas, tempo longo demais para uma pandemia. Avanços vêm ocorrendo no processo de produção de uma vacina para uma eventual pandemia, porém, ainda existem inúmeros obstáculos a serem transpostos antes de se obtê-la.

Paralelamente, a vacinação anual deve continuar e, idealmente, ser ampliada. Hoje, no Brasil, as campanhas anuais alcançam uma excelente cobertura em pessoas com idade acima de 60 anos. No entanto, a cobertura vacinal em profissionais da saúde e em crianças e adultos com risco aumentado de complicações ainda deixa muito a desejar. A vacinação desses dois grupos - o primeiro, por maior exposição, o segundo, pela maior morbidade e mortalidade - deve ser um dos esteios de qualquer plano de contingência, a única diferença é que começa agora, com ou sem pandemia. A adesão à vacinação anual cria a cultura da vacinação contra a influenza, facilitando uma vacinação emergencial durante uma eventual pandemia.

Como visto anteriormente, os vírus da influenza sofrem mutações freqüentes, além de recombinarem genes entre si. Tais mutações, geralmente de pequena expressão, resultam nas mudanças, geralmente anuais, dos vírus da influenza, explicando a ocorrência de epidemias a cada ano.

Quando os vírus recombinam genes com vírus de outras espécies (na maioria das vezes de aves ou suínos), pode resultar num vírus que determine uma pandemia. Pandemias de influenza vêm ocorrendo numa freqüência de cerca de três a cada século, pelo menos desde o século XVI (com exceção do século XVII), 
quando se tem notícia da primeira pandemia - embora outras possam ter ocorrido anteriormente.

No século passado, foram três, a última em 1968. Desde a detecção de casos humanos de um vírus recombinante, o H5N1 (também conhecido como o vírus da influenza aviária), em 1997, em Hong Kong, se espera a ocorrência de uma nova pandemia. $\mathrm{O}$ vírus da influenza A H5N1 é altamente letal, ainda que de transmissão inter-humana muito rara. A totalidade dos casos se deu após o contato com aves doentes. Ao longo de um pouco mais de dez anos após a ocorrência dos primeiros casos humanos, já se verificaram, segundo a OMS, 385 casos humanos com 253 óbitos (até junho de 2008), uma letalidade de 63\%. Ou seja, cerca de dois terços dos casos morreram. Esse número, muito provavelmente, é uma subestimativa, uma vez que a OMS somente informa os casos confirmados laboratorialmente, o que explicaria, em parte, a alta letalidade, uma vez que os casos com confirmação laboratorial tendem a ser os mais graves. A quase totalidade desses casos ocorreu (e ocorre) na Ásia, sendo a Indonésia o país com o maior número, 135, seguido do Vietnã, com 106.

Não se pode ter certeza de que o H5N1 sofrerá mudanças que lhe permitam ser facilmente transmitido de humano para humano, o que poderia resultar numa pandemia. Porém, ele pode ser considerado o principal 'suspeito' de uma próxima pandemia. Uma vez estabelecida a transmissão inter-humana, dificilmente esse vírus deixaria de ser introduzido no Brasil. Nas pandemias anteriores, pelo menos desde o final do século XIX, a introdução da variante pandêmica se verificou devido ao intenso movimento de pessoas viajando de avião entre os continentes. E isso pouco provavelmente deixaria de ocorrer. 


\section{VÍRUS E CÂNCER}

A hipótese de que determinados cânceres tivessem etiologia viral foi levantada no alvorecer da microbiologia, no final do século XIX. Já no início do século XX, a doença de Roux, um câncer de aves, teve sua etiologia viral demonstrada, mas a demonstração de que cânceres humanos fossem efetivamente causados por vírus somente se deu na segunda metade do século XX.

Estima-se que cerca de 15 a 20\% de todos os cânceres de humanos sejam determinados por vírus. Vírus são parasitas de vida intracelular obrigatória e determinam a formação de proteínas que alteram a programação da célula hospedeira, afetando a proliferação, diferenciação e morte das células, sua integridade genética e suas características antigênicas externas, alterando seu reconhecimento pelo sistema imune do organismo hospedeiro.

Hoje, a etiologia viral de algumas neoplasias humanas está claramente demonstrada. Muito importante lembrar que, muitas vezes, se trata mais de uma co-participação: a presença do vírus não é causa suficiente, nem causa necessária, agindo, portanto, como um fator de risco a mais. Algumas neoplasias, no entanto, podem ser efetivamente consideradas doenças virais. Quanto ao seu caráter 'emergente', fica mais difícil avaliar, principalmente porque dados precisos de incidência ou prevalência de neoplasias não são disponíveis na maioria das vezes, muito menos com registro histórico.

Das neoplasias comprovadamente de etiologia viral e com impacto em saúde pública, duas se destacam: o câncer do colo uterino e o hepatocarcinoma, o primeiro com um impacto muito maior. 


\section{Câncer do colo uterino}

O câncer do colo uterino teve sua etiologia viral claramente demonstrada há cerca de vinte anos. Trata-se do papilomavírus humano (HPV, sigla derivada do inglês human papillomavirus). A principal neoplasia determinada pelos vírus HPV é o câncer de colo uterino, no qual eles são causa determinante em virtualmente $100 \%$ dos casos. Os tipos mais freqüentemente associados a essa neoplasia são os HPV 16, 18, 31 e 45, os dois primeiros perfazendo cerca de $70 \%$ dos casos mundialmente (Quadro 1). Outras neoplasias estão associadas com os HPV, mas estes não seriam os únicos determinantes, uma vez que a associação é menor. As principais são o câncer de pênis, de vulva, de vagina, de epitélio estratificado anal, de boca, de esôfago e de laringe.

Existem duas formas de carcinoma de colo uterino: os de epitélio escamoso e o adenocarcinoma, ocorrendo numa proporção aproximada de $80 \%$ e $20 \%$, respectivamente. O câncer de colo uterino é a segunda ou terceira causa de morte por neoplasias em mulheres em quase todo o mundo, particularmente nos países em desenvolvimento. Calcula-se que a incidência anual seja de quinhentos mil casos em todo o mundo, com cerca de 270 mil mortes. E estima-se que mundialmente, a cada momento, existam cerca de 1,4 milhão de mulheres vivendo com câncer do colo uterino.

$\mathrm{Na}$ América Latina, ocorre cerca de 14\% do total mundial de casos e $12 \%$ do total de óbitos, o que significa 72 mil casos e 33 mil óbitos anuais. O câncer de colo uterino determina um número de anos de vida perdidos que é superior aos determinados pela Aids, pela tuberculose ou pelos cânceres de mama, pulmão ou estômago.

A infecção genital por HPV é a infecção sexualmente transmitida mais comum nos países desenvolvidos, sendo 
estimado que cerca de trinta milhões de casos novos são diagnosticados a cada ano em todo o mundo. A infecção pelo HPV é assintomática, ainda que possa ser detectada pela presença de displasias celulares nas células de descamação do epitélio do colo uterino.

Os HPV são DNA vírus de dupla fita, pequenos, medindo cerca de $55 \mathrm{~nm}$ de diâmetro, esféricos, não encapsulados, com uma dupla cápside. Apresentam um genoma simples, com cerca de $8 \mathrm{~kb}$ (oito mil bases) e dez genes. Até recentemente classificados dentro da família Papovaviridae, estão numa família própria, Papillomaviridae.

Atualmente, existem cerca de cem diferentes tipos conhecidos de HPV, classificados pela seqüência de bases do gene L1, que codifica a principal proteína da cápside externa e também a proteína constituinte das vacinas. A denominação dos diferentes tipos se dá pela ordem seqüencial de descrição. Desses, cerca de trinta tipos infectam a mucosa anogenital, alguns deles determinando neoplasias.

Os HPV, como outros papilomavírus, são altamente espécieespecíficos, não sendo conhecida infecção cruzada entre humanos e animais. Alguns tipos de HPV ainda são subdivididos em subtipos e variantes. Com mais de $10 \%$ de variação na seqüência de bases, trata-se de um tipo diferente; variação de 2 a 10\% determina um subtipo; e variação menor de $2 \%$, uma variante.

Os HPV podem ser classificados em duas grandes categorias, os que determinam infecção cutânea e os que determinam infecção mucosa. Os HPV com tropismo cutâneo são amplamente encontrados na população, particularmente em crianças, e provocam a verruga comum e outras manifestações menos usuais, não apresentando tendência a malignização. 
Os HPV com tropismo para mucosas podem determinar neoplasias, sendo divididos em alto risco e baixo risco ou, alternativamente, oncogênicos e não-oncogênicos. Ainda que a oncogênese seja um processo complexo, que somente ocorre com determinados tipos de HPV, uma etapa crítica seria a inibição da apoptose das células do epitélio escamoso, que normalmente ocorre ao longo da migração das células da camada basal para a superfície. Esta discussão se restringe aos HPV com tropismo mucoso, por serem os que levam ao câncer.

O genoma dos HPV é circular e conta com dez genes, oito de expressão precoce (E, early) e dois de expressão tardia (L, late). Estes últimos codificam as proteínas da cápside, L1 e L2, imunogênicas. Os genes de expressão precoce (E1 a E8) codificam diferentes funções essenciais ao vírus, como replicação, sendo que os genes E6 e E7 desempenham importante papel na oncogênese.

\section{VÍRUS E IMUNOSSUPRESSÃO}

O aumento do número de procedimentos médicos que levam ao comprometimento, muitas vezes intenso, da imunidade (como os transplantes e a quimioterapia para neoplasias e doenças autoimunes) e o crescente número de pessoas vivendo com Aids fazem com que algumas doenças virais tenham passado da categoria de curiosidades raras a problemas sérios.

Pelo menos dois grandes grupos de pacientes imunocomprometidos são os mais afetados por doenças virais: os pacientes com Aids e os submetidos a transplante de órgãos ou medula óssea. A introdução da terapêutica anti-retroviral há pouco mais de dez anos reduziu consideravelmente a imunossupressão dos pacientes com Aids, desde que respondam bem ao tratamento. 
Já em pacientes submetidos a transplantes e pacientes com outras modalidades de imunossupressão (como os submetidos à quimioterapia antineoplásica), a morbidade e mortalidade ainda são significativas. Tratamentos para doenças bacterianas e fúngicas são desenvolvidos em maior quantidade do que para doenças virais. Por isso, essas últimas estão se transformando em problemas de solução mais difícil.

Dentre os vírus que afetam pacientes com imunossupressão, muitos não podem ser considerados emergentes, uma vez que são conhecidos há décadas, como, por exemplo, os vírus da varicela-zoster, o de Epstein-Barr e o do herpes simplex tipo 1. Outros vírus foram reconhecidos apenas há pouco tempo, como o herpes vírus humano 8 (HHV-8), identificado como o agente causal do sarcoma de Kaposi, um tumor de vasos sangüíneos.

\section{OUTRAS POSSÍVEIS DOENÇAS VIRAIS}

O grande desenvolvimento da biologia molecular impulsionou a pesquisa com vírus, por meio dos métodos de detecção de RNA ou DNA em material biológico. O isolamento dos vírus em cultura, muitas vezes difícil e mesmo perigoso, passou a ser feito com relativa facilidade. Isso levou à detecção de vírus ou material viral associados a diferentes enfermidades, desde neoplasias até obesidade e doença mental. Muitas dessas associações se mostraram espúrias, ou seja, sem nexo causal. No entanto, muitas delas foram comprovadas, como a associação dos vírus HPV e o câncer do colo uterino. Objeto de muita discussão e pesquisa são associações que viriam a derrubar velhos paradigmas, como a eventual etiologia viral da obesidade e de algumas doenças mentais. 
Os critérios para aceitar que uma determinada doença seja de fato infecciosa e causada por este ou aquele microrganismo é tema de discussão desde o nascimento da microbiologia. Até época recente, os critérios estabelecidos por Robert Koch, no final do século XIX, eram o 'padrão ouro' para estabelecer a associação causal. Segundo Koch, o agente infeccioso deveria poder ser isolado de um caso da doença, ser cultivado em laboratório e causar a doença quando inoculado em animal experimental. Koch trabalhava com bactérias e esses princípios serviram por algumas décadas. Com os vírus, preencher esses requisitos muitas vezes é impossível, assim como com algumas bactérias.

O desenvolvimento da biologia molecular determinou um incremento qualitativo da capacidade de identificar microrganismos. A microbiologia clássica é essencialmente morfológica, imunológica e bioquímica, identifica e classifica os microrganismos pelo seu aspecto, pelos seus antígenos e pela sua capacidade de realizar determinadas reações bioquímicas. A biologia molecular se vale da identificação genética dos microrganismos, através da identificação de determinados (ou mesmo todos) genes. Isso aumenta muito a sensibilidade em detectar a infecção, porém cria dificuldades em estabelecer a causalidade. Adiante estão alguns interessantes exemplos de associações entre vírus e determinadas patologias ainda não claramente compreendidas e ainda não aceitas como de causalidade.

\section{Obesidade como infecção emergente}

Recentemente, pelo menos um vírus vem sendo associado à obesidade, sugerindo que uma parte dos casos de obesidade mórbida seja de fato causada por este adenovírus. As evidências ainda são frágeis e sujeitas a revisões. Não se sabe se o papel do 
vírus seja de agente etiológico de fato ou de co-fator no desenvolvimento da obesidade.

Um aspecto atraente desse modelo é o caráter epidêmico da obesidade em anos recentes, sugerindo, realmente, uma doença infecciosa. A obesidade é uma doença crônica grave, com diversas complicações, e multifatorial em suas causas.

A prevalência da obesidade vem crescendo de maneira dramática nas últimas décadas, particularmente nos países industrializados, mas nos países em desenvolvimento também. Esse crescimento rápido e a disseminação ampla são compatíveis com uma etiologia infecciosa.

Já foram identificados pelo menos cinco vírus de animais e três de humanos com capacidade de induzir a obesidade em animais de laboratório. São eles: vírus da cinomose (próximo ao vírus do sarampo), vírus Rous tipo 7, vírus Borna (também associado à doença mental), o agente do Scrapie (esse não propriamente um vírus, como já foi dito anteriormente) e o vírus SMAM-1, um adenovírus de aves isolado na Índia. Os quatro primeiros induzem a obesidade por ação no sistema nervoso central; o último por ação direta nos adipócitos, sendo o único vírus animal até agora associado à obesidade humana.

Os três vírus de humanos são os adenovírus (Ad) 36, 37 e 5, todos com ação direta sobre os adipócitos. Esses vírus estimulam enzimas e fatores de transcrição que determinam o acúmulo de triglicérides e conduzem à diferenciação de pré-adipócitos em adipócitos maduros. Os vírus Ad-5 e Ad-37 determinam a obesidade em animais de laboratório. O vírus Ad-36 é o mais estudado até o momento e é o único adenovírus humano associado à obesidade humana. Este vírus induz a obesidade em galinhas, camundongos, ratos e macacos e foi encontrado em 
$30 \%$ dos obesos em um estudo em humanos, e apenas em 11\% nos não obesos. Em pares de gêmeos discordantes para a infecção pelo Ad-36, os com evidência de infecção pelo Ad-36 eram mais pesados e mais gordos que os irmãos.

O crescente número de estudos sobre vírus e obesidade corrobora a teoria de que, pelo menos em parte, o dramático crescimento da obesidade em todo o mundo seja devido a uma infecção viral.

\section{Vírus e doença mental}

Há anos um vírus causador de doença em cavalos vem sendo associado a determinadas doenças mentais, particularmente quadros depressivos graves. O vírus Borna foi identificado na Europa há várias décadas e já se mostrou uma associação de infecção humana prévia e doença mental. Essa associação não é suficientemente forte para ser aceita facilmente, mas constitui tema para interessantes especulações.

\section{VÍRUS E GUERRA BIOLÓGICA}

O uso de agentes biológicos como arma não é novidade para a humanidade. Durante séculos, a guerra biológica tem sido objeto de muita pesquisa e especulação, mas de pouca ação. $\mathrm{O}$ medo de efeitos contrários e dúvidas sobre sua eficiência como arma deve ter limitado seu uso. Recentemente, se verificou uma nova forma de terrorismo, empregando agentes infecciosos devagar e sem muito alarde, até as ocorrências recentes com o Bacillus anthracis nos Estados Unidos. A varíola é possivelmente o mais devastador desses agentes. Passados quase trinta anos desde sua erradicação, a saúde pública tem de lidar com a possibilidade de sua reintrodução. 
Em tese, praticamente qualquer agente biológico pode ser usado como arma. O B. anthracis, o vírus da varíola, a Yersinia pestis e a toxina do Clostridium botulinum podem ser considerados os 'clássicos' das armas biológicas. Desses, dois já foram sérios problemas de saúde pública: o vírus da varíola e a $Y$. pestis.

$O$ vírus da varíola talvez seja o mais preocupante dos agentes potencialmente utilizáveis como arma biológica. Causador de epidemias devastadoras até época recente, seu desaparecimento não se deu de forma natural, mas por força de uma campanha mundial de erradicação através da vacinação, a primeira doença a ser erradicada por ação humana deliberada. O último caso de varíola se deu em 1977, mas ainda houve um último caso documentado em 1978, em Birmingham, na Inglaterra, resultado de um acidente de laboratório em que houve disseminação do vírus num centro de pesquisa.

A disponibilidade do vírus é desconhecida. Supostamente, somente os Estados Unidos e a Rússia teriam ainda vírus estocado. Pouco depois da erradicação da varíola, a Assembléia da OMS determinou a destruição dos estoques existentes. Todos os países teriam concordado e destruído seus estoques, com exceção dos Estados Unidos e da então União Soviética. A decisão de destruir os dois estoques restantes foi tomada em 2002, mas talvez não tenha sido respeitada, principalmente porque persistia a suspeita de que estoques do vírus estariam em mãos de terroristas. Não se sabe se alíquotas de vírus foram desviadas para laboratórios de outros países com programas de armas biológicas, como o Iraque.

A vacinação contra a varíola foi interrompida no início da década de 1980, ainda que em alguns países da América do Norte e da Europa Ocidental isso tenha ocorrido alguns anos antes. A reintrodução da varíola determinaria um número elevado de 
casos, uma vez que mais de $40 \%$ da população mundial nunca foi vacinada e o restante deve ter imunidade declinante.

A letalidade da varíola é de cerca de 30\%. É uma doença altamente contagiosa: se o vírus fosse veiculado no aeroporto de uma grande cidade, não só haveria um elevado número de casos, mas estes seriam dispersados por praticamente todo o mundo, lembrando que o período de incubação da varíola varia de 7 a 17 dias, geralmente de 12 a 14. Em 1972, um peregrino retornou de Meca para a então Iugoslávia com febre. Nas quatro semanas seguintes ao seu retorno, 150 pessoas adoeceram em diversos lugares. Foi esse o tempo necessário para se chegar, finalmente, ao diagnóstico de varíola.

\section{0 ressurgimento da varíola no Brasil:}

\section{cenários possíveis}

A natureza imprevisível do terrorismo não permite que país nenhum se escuse de considerar a possibilidade de ser ele o alvo, intencional ou não, de um ataque com arma biológica. Difícil prever as conseqüências da reintrodução da varíola no Brasil. É razoável aceitar que, mais provavelmente, se daria num grande centro urbano do Sudeste, possivelmente em São Paulo ou no Rio de Janeiro. Um cenário plausível seria o da chegada de um ou mais indivíduos infectados no decorrer de um ato de bioterrorismo num aeroporto norte-americano ou europeu ocidental.

Mesmo se um único paciente infectado em outro país chegasse ao Brasil no período de incubação, teria a possibilidade de transmitir a doença a um número elevado de pessoas, a exemplo do que ocorreu na Iugoslávia em 1972. Se esse paciente for um terrorista que tenha sido infectado deliberadamente para se 
transformar num agente disseminador de varíola, o número de pessoas passíveis de se infectar a partir dele torna-se muito maior.

O controle da varíola é feito através da vacinação, não há tratamento eficaz. O Brasil não dispõe de estoque estratégico de vacinas. A produção da vacina era nacional, o que pressupõe a possibilidade da sua retomada, uma medida a ser feita independentemente da ocorrência de caso(s). O custo da vacina não é elevado. Sem dúvida, deverá se optar pela vacina antiga, com produção do vírus em bezerros. Essa vacina oferece uma boa proteção, mas não podemos esquecer que a varíola anteriormente existente no Brasil era a varíola minor, ou alastrim, com letalidade baixa, de 1\%, comparada com $30 \%$ na varíola major. O uso da varíola como arma biológica, sem dúvida, deve ser com a varíola major.

A vacina da varíola apresenta um alta incidência de efeitos colaterais, sendo estimada uma letalidade de um óbito para cada um milhão de pessoas vacinadas, isso numa época de poucos indivíduos imunocomprometidos. Esta relativamente alta incidência de eventos adversos é o principal aspecto que contraindica a estratégia de vacinação em massa. Além disso, há a dificuldade operacional de vacinar um grande número de pessoas num espaço curto de tempo, principalmente desde que os injetores de pressão foram considerados de risco para a transmissão de vírus como os das hepatites B e C e o da Aids. A vacinação de pessoal de maior risco, como funcionários de aeroportos e hospitais, bombeiros e policiais, estaria na dependência da magnitude e continuidade do risco, isto é, a possibilidade de um número maior de casos-índice.

Algumas medidas seriam razoáveis para serem adotadas inicialmente: a obtenção de um estoque estratégico de vacinas 
contra a varíola e o aprimoramento dos sistemas de vigilância epidemiológica para fazer frente a um novo tipo de ameaça de introdução de uma doença.

A vacinação de bloqueio foi a tática mais eficiente da campanha de erradicação e, sem dúvida, deverá ser empregada no caso da reintrodução da varíola. Para tanto, há necessidade de recursos humanos adequadamente treinados, pois a geração que conduziu a campanha de erradicação já está, em sua maioria, aposentada.

A saúde pública se vê agora com uma incumbência adicional: neutralizar ou minimizar as conseqüências de atos de bioterrorismo, uma incumbência que lhe é, até certo ponto, estranha, pois implica o envolvimento com ações policiais, agregando a criminalística à epidemiologia.

Nessa nova perspectiva da saúde pública, o impensável se tornou realidade e não existe quem tenha experiência anterior. Um inevitável período de aprendizado ocorrerá, cabe empreender esforços para que seja curto e com o menor número de conseqüências desagradáveis.

\section{Aquecimento gLOBAL E VIROSES EMERGENTES: REALIDADE OU FANTASIA?}

A relação entre clima e doença é tema de discussão em medicina desde Hipócrates. As posições e opiniões desde então variaram mais do que o próprio clima. As oscilações climáticas da Terra são fato, as temperaturas médias do planeta vêm apresentando uma tendência de crescimento razoavelmente constante nos últimos 250 a 300 anos. Apesar dessa tendência, ciclos de decréscimo ocorrem (o último foi da década de 1940 à de 1980). Desde então, a tendência sofreu uma inversão e o planeta vive um período de aquecimento. As conseqüências desse 
fenômeno têm sido amplamente discutidas, assim como suas possíveis causas: não se trataria apenas de um ciclo natural, mas o resultado do aumento da emissão de dióxido de carbono $\left(\mathrm{CO}_{2}\right)$, determinado pela crescente queima de combustíveis fósseis.

Entre as conseqüências do aquecimento global, estaria o recrudescimento de determinadas doenças infecciosas, particularmente as transmitidas por vetor. Malária, dengue, doença de Lyme e febre do Nilo Ocidental são exemplos de problemas atuais de saúde pública, tanto de países 'tropicais' em desenvolvimento (como malária e dengue), como de países industrializados e de clima temperado (como doença de Lyme e febre do Nilo Ocidental). Esta última é uma doença 'tropical' (foi descrita inicialmente em Uganda) que ocorre nos Estados Unidos e no Canadá.

Nos países de clima temperado, uma elevação discreta das temperaturas médias pode determinar invernos brandos, primaveras chuvosas e temperaturas amenas por períodos mais prolongados, o suficiente para permitir que vetores e hospedeiros silvestres encontrem condições de vida mais favoráveis. Teríamos aí uma expansão das áreas de transmissão dessas doenças.

Estudos referentes ao fenômeno El Niño sugerem que determinadas doenças apresentam um incremento da sua incidência ao final de um ciclo, como a hantavirose no sudoeste dos Estados Unidos, que teve um surto após um período de invernos brandos e primaveras chuvosas, levando a um crescimento populacional dos roedores silvestres. A malária no Quênia e na Venezuela parece também ser intensificada pelo fenômeno.

Há o reverso da moeda: uma análise histórica da malária na Inglaterra mostra que ocorreu durante o período conhecido 
como a 'pequena idade do gelo', entre meados do século XVI e meados do século XVIII, desaparecendo quando se iniciava um ciclo de aquecimento.

A determinação da ocorrência e distribuição das doenças infecciosas é complexa. Não existem determinantes únicos e isolados. Essas doenças são resultantes do contexto de um determinado momento histórico e é preciso buscar as causas na interação de inúmeros fatores. Clima é um deles, sem dúvida importante, mas apenas mais um, cujo peso relativo pode ser suplantado por outros igualmente importantes, como a desigualdade social ou a degradação urbana, por exemplo.

$\mathrm{O}$ aquecimento global não parece ser fator necessário e muito menos suficiente para determinar o recrudescimento de determinadas doenças infecciosas, salvo, porém, se nada for feito para o seu controle. 



\section{Futuro a Curto, Médio e LONGO Prazos}

$\mathbf{N}$ ada mais equivocado do que fazer previsões sobre a ocorrência de doenças infecciosas. No entanto, vamos nos permitir elaborar alguns cenários possíveis. A única maneira efetiva de controlar a disseminação de uma doença viral é por meio de vacinas. Há alguns exemplos já citados: varíola, poliomielite e sarampo. Essas são três doenças virais erradicadas (a varíola) ou controladas (sarampo e poliomielite). Ainda que milhares de crianças ainda morram em conseqüência do sarampo a cada ano, particularmente na África e no Sudeste Asiático, o controle do sarampo nas Américas mostrou ser possível, inclusive, sua erradicação, desde que exista vontade política.

Mesmo que as vacinas atualmente disponíveis não sejam suficientes para controlar diversas doenças virais existentes, muitas vezes é possível reduzir de maneira significativa a morbidade e mortalidade resultantes dessas doenças, como no caso da caxumba, da rubéola, da febre amarela e da diarréia por rotavírus.

$E$ as viroses 'emergentes'? Aqui existe um problema no tocante ao desenvolvimento de vacinas. Afora a dengue e a Aids, com centenas de milhares de casos anuais em diferentes continentes, as outras infecções virais 'emergentes' são geralmente de baixa incidência, com poucos casos. Isso desencoraja o investimento privado em pesquisa e desenvolvimento de vacinas, uma vez que o retorno é incerto, obrigando governos e organizações internacionais a buscarem recursos para o desenvolvimento de 
vacinas para doenças assim ditas 'negligenciadas'. Doenças 'negligenciadas' são quase sempre infecciosas, para as quais não existe estímulo comercial para desenvolver drogas ou vacinas. Entretanto, um movimento nesse sentido vem ocorrendo nos últimos anos e é possível esperar resultados na próxima década.

Mesmo quando existe uma perspectiva promissora de retorno do investimento, como no caso da dengue e da Aids, permanecem obstáculos que devem ser superados. Um exemplo é a comparação entre o vírus HIV, descoberto em meados da década de 1980, e o vírus HPV, cuja associação causal com o câncer do colo uterino foi demonstrada por volta da mesma época. Com um investimento possivelmente menor do que o já feito até hoje na busca por uma vacina para a Aids, duas vacinas efetivas e seguras contra os HPV já estão comercializadas, porém ainda estamos longe de dispor de uma vacina efetiva e segura contra a Aids. A explicação está na complexidade da resposta imune induzida pelo HIV, ainda não inteiramente dominada. É de se esperar, portanto, que o futuro a curto e médio prazos não seja muito diferente da situação atual - isso se novos vírus não emergirem e passarem a constituir problema de saúde pública.

Diante da perspectiva de não dispor de vacinas para controlar de maneira efetiva muitas das doenças virais existentes, além da possibilidade do surgimento de novas, que alternativas restam para os serviços de saúde pública? Das inúmeras discussões, análises e propostas feitas, parece um consenso que o aprimoramento da vigilância epidemiológica é a base das medidas a serem implantadas para fazer frente à nova realidade. Não há qualquer novidade nisso, muito pelo contrário: outras disciplinas científicas que lidam com contextos de previsão difícil, senão impossível, como a meteorologia e a economia, sempre 
buscaram aperfeiçoar seus sistemas de vigilância, entendendo que os fenômenos estudados compõem um sistema interdependente, não havendo fatos inconseqüentes.

A mais clássica das recomendações para o enfrentamento das doenças infecciosas emergentes, a do Institute of Medicine $(\mathrm{IOM})$, dos Estados Unidos, dedica uma parte substancial à vigilância epidemiológica, mostrando que, sem um adequado sistema, de nada vale o esforço e o investimento em pesquisa, outra das prioridades estabelecidas (Childs et al., 1984; De Wit \& Fouchier, 2008).

Mais do que apenas recomendar uma intensificação da vigilância epidemiológica, o relatório do IOM especifica que a integração entre o aprimoramento e a disponibilidade dos recursos laboratoriais, a pesquisa básica e a existência de sistemas de intervenção rápida de nada valerão sem o investimento em vigilância.

O novo cenário das doenças infecciosas - um cenário de doenças em constante e acelerada mudança - traz, muito mais do que a emergência de algumas doenças, a necessidade de uma adaptação das estratégias para o seu controle. Programas de vigilância e controle baseados na premissa de um contexto epidemiológico razoavelmente estável já não produzem os resultados esperados. Após umas poucas décadas de sucesso no controle das doenças transmissíveis - malária, sífilis, tuberculose, para citar algumas -, em todo o mundo os serviços de saúde se depararam não só com a recrudescência de casos destas doenças - com algumas notáveis exceções, pelo menos até o momento, como varíola, doença de Chagas e dracunculose -, mas também com o surgimento de novas doenças ou de variantes das antigas: Aids, tuberculose multirresistente, Vibrio cholerae 0139, Escherichia coli 0157 H7, variante da doença de Creutzfeldt-Jakob, dengue 
hemorrágico e outras mais, para não falar das mais sensacionais febres de Ebola e de Lassa. Destas, a varíola dos macacos, uma das primeiras doenças para a qual se previu um papel de doença emergente depois de décadas de aparente inatividade, tem um recente aumento de incidência. Neste contexto, a disponibilidade de informação e a agilidade da ação, com flexibilidade das estratégias de controle, passam a ser fundamentais.

A evolução tecnológica verificada na biologia e na informática (Dowdle, 1997) não trouxe apenas recursos mais sofisticados, mas os tornou mais acessíveis. A infra-estrutura necessária para o acesso e o processamento da informação e para a realização de exames laboratoriais relativamente sofisticados vem gradativamente diminuindo de custo, de modo que a democratização da informação é uma conseqüência inevitável do processo.

A vigilância epidemiológica evoluiu muito desde o início do século XX. Até então, restringia-se basicamente a mera coletânea de registros de doenças, muitas vezes com o intuito de impor medidas de quarentena ou de isolamento. A campanha de erradicação da varíola deixou clara a importância da vigilância epidemiológica como meio de viabilizar a intervenção rápida. A existência de sistemas eficazes de vigilância epidemiológica é a base da consolidação do controle e da erradicação de diversas doenças infecciosas, como poliomielite, malária e sarampo.

A importância das doenças infecciosas emergentes como problema de saúde pública em nível mundial é evidenciada por sua inclusão pela OMS como temática principal do Dia Mundial da Saúde de 1997. Ao contrário do contexto tradicional das doenças infecciosas endêmicas e epidêmicas, a característica principal das doenças emergentes é a variabilidade do seu padrão epidemiológico e uma certa imprevisibilidade da sua evolução, 
de modo que, principalmente pela inexistência de modelos confiáveis, qualquer programa de controle deverá se basear em informações recentes.

A vigilância epidemiológica é hoje a ferramenta metodológica mais importante para a prevenção e o controle de doenças em saúde pública. É consensual no discurso de todas as entidades de saúde pública mundo afora, desde as de âmbito internacional até as de abrangência local, que não existem ações de prevenção e controle de doenças com base científica que não estejam estruturadas sobre sistemas de vigilância epidemiológica.

$\mathrm{Na}$ primeira metade da década de 1960, consolidou-se internacionalmente uma conceituação mais abrangente de vigilância epidemiológica, em que eram explicitados seus propósitos, funções, atividades, sistemas e modalidades operacionais. Vigilância epidemiológica foi, então, definida como:

o conjunto de atividades que permite reunir a informação indispensável para conhecer, a qualquer momento, o comportamento ou história natural das doenças, bem como detectar ou prever alterações de seus fatores condicionantes, com o fim de recomendar oportunamente, sobre bases firmes, as medidas indicadas e eficientes que levem à prevenção e ao controle de determinadas doenças. (Waldman, 1998: 7)

No Brasil, esse conceito foi inicialmente utilizado em alguns programas de controle de doenças transmissíveis coordenados pelo Ministério da Saúde, notadamente a Campanha de Erradicação da Varíola (CEV), de 1966 a 1973. A experiência da CEV motivou a aplicação dos princípios de vigilância epidemiológica a outras doenças evitáveis por imunização, de forma que, em 1969, foi organizado um sistema de notificação semanal de doenças, baseado na rede de unidades permanentes 
de saúde e sob a coordenação das secretarias estaduais de Saúde. As informações de interesse desse sistema passaram a ser divulgadas regularmente pelo Ministério da Saúde, em um boletim epidemiológico de circulação quinzenal. Tal processo propiciou o fortalecimento de bases técnicas que serviram, mais tarde, para implementar programas nacionais de grande sucesso na área de imunizações, sobretudo na erradicação da transmissão autóctone do poliovírus selvagem na região das Américas.

Em 1975, por recomendação da $5^{\text {a }}$ Conferência Nacional de Saúde, foi instituído o Sistema Nacional de Vigilância Epidemiológica (SNVE). Este sistema - formalizado pela lei n. 6.259, do mesmo ano, e pelo decreto n. 78.231, que a regulamentou, em 1976 - incorporou o conjunto de doenças transmissíveis então consideradas de maior relevância sanitária no país. Buscava-se, na ocasião, compatibilizar a operacionalização de estratégias de intervenção desenvolvidas para controlar doenças específicas, através de programas nacionais que eram, então, escassamente interativos.

A promulgação da lei n. 8.080, que instituiu, em 1990, o Sistema Único de Saúde (SUS), teve importantes desdobramentos na área de vigilância epidemiológica. O texto legal manteve o SNVE, oficializando o conceito de vigilância epidemiológico como:

um conjunto de ações que proporciona o conhecimento, a detecção ou prevenção de qualquer mudança nos fatores determinantes e condicionantes de saúde individual ou coletiva, com a finalidade de recomendar e adotar as medidas de prevenção e controle das doenças ou agravos.

Embora essa definição não modifique a essência da concepção até então adotada pelo SNVE, ela faz parte de um contexto de profunda reorganização do sistema de saúde brasileiro, que prevê 
a integralidade preventivo-assistencial das ações de saúde e a conseqüente eliminação da dicotomia tradicional entre essas duas áreas, o que tanto dificultava as ações de vigilância. Além disso, um dos pilares do novo sistema de saúde passou a ser a descentralização de funções, sob comando único em cada esfera de governo (federal, estadual, municipal), o que implica o direcionamento da atenção para as bases locais de operacionalização das atividades de vigilância epidemiológica no país.

Dessa forma, atualmente o SNVE estabelece como prioridade o fortalecimento de sistemas municipais de vigilância epidemiológica dotados de autonomia técnico-gerencial para enfocar os problemas de saúde próprios de suas respectivas áreas de abrangência. Espera-se, assim, que os recursos locais sejam direcionados para atender, prioritariamente, às ações demandadas pelas necessidades da área, em termos de doenças e agravos que lá sejam mais prevalentes.

Nessa perspectiva, a reorganização do SNVE deve pautarse nos seguintes pressupostos, que resultaram de amplo debate nacional entre os técnicos da área, com base nos preceitos da Reforma Sanitária instituída e implementada no país: heterogeneidade do rol de doenças e agravos sob vigilância no nível municipal, embora apresentando, em comum, aquelas que tenham sido definidas como de interesse do sistema nacional e do estadual correspondente; distintos graus de desenvolvimento técnico, administrativo e operacional dos sistemas locais, segundo o estágio de organização da rede de serviços em cada município; incorporação gradativa de novas doenças e agravos (inclusive doenças não transmissíveis) aos diferentes níveis do sistema; fluxos de informações baseados no atendimento às necessidades do sistema local de saúde, sem prejuízo da transferência, em 
tempo hábil, de informações para outros níveis do sistema; construção de programas de controle localmente diferenciados, respeitadas as bases técnico-científicas de referência nacional.

A relação de doenças de notificação nacional tem sofrido revisões durante as últimas décadas, em função de novas ações programáticas instituídas para controlar problemas específicos de saúde. Em 1998, o Centro Nacional de Epidemiologia (Cenepi) procedeu a uma ampla revisão do assunto, que resultou na explicitação de conceitos técnicos sobre o processo de notificação, bem como dos critérios utilizados para a seleção de doenças e agravos notificáveis. Essa orientação servirá de base para atualizar a relação de doenças de notificação compulsória em âmbito nacional.

Em 2003, as atividades de vigilância epidemiológica e de controle de doenças foram retiradas da Funasa e colocadas na recém-criada Secretaria de Vigilância da Saúde (SVS), órgão da administração direta do Ministério da Saúde. Esta medida administrativa segue uma tendência mundial de reunir todas as ações de vigilância numa só entidade. Até então, a vigilância e os programas de controle da Aids, tuberculose e hanseníase não estavam agrupados, ficando separados em áreas distintas do Ministério da Saúde. Com a criação da SVS, todas essas atividades foram reunidas numa só entidade administrativa, incluídas a vigilância das doenças e dos agravos não transmissíveis e a vigilância ambiental, duas vertentes até então virtualmente ignoradas. 
É chegada a hora de finalizar este livro. Acima de tudo, a mensagem básica que gostaríamos que ficasse na mente do leitor é que a emergência de uma doença viral é um processo que vem ocorrendo há milênios no interior das comunidades humanas, mas a velocidade desse processo sofreu uma aceleração significativa nas últimas décadas. É de se esperar, portanto, que assim continue em futuro próximo. A emergência de uma nova virose ou o crescimento do número de casos de uma velha conhecida não significa, necessariamente, a falência da saúde pública. Reflete as mudanças, boas ou ruins, em uma sociedade.

A crescente consciência ecológica fez com que se incluísse no planejamento de obras uma análise do impacto ambiental esperado. Talvez fosse chegado o momento de estender essa análise, acrescentando-se uma seção dedicada ao impacto esperado sobre a ocorrência de doenças infecciosas.

A imensa maioria das viroses emergentes tem sua origem em zoonoses que se adaptam à transmissão inter-humana. Vírus fazem parte da natureza, e a preservação da natureza mantém o que ela tem de bom e de ruim, sem distinção. A proteção do meio ambiente exige disciplina e respeito, sem o que a natureza nos dará o devido troco. A maneira como as diferentes sociedades exploram a natureza é fator crítico para a emergência de doenças virais e a crescente indústria do ecoturismo deve ser lembrada dos riscos de adoecimento. Para os que buscam apreciar a natureza, há necessidade de cuidados. 



\section{REFERÊNCIAS}

ATKINSON, R. L. Viruses as an etiology of obesity. Mayo Clinic Proceedings, 82(10): 1.192-1.198, 2007.

BRASIL. Ministério da Saúde. Secretaria de Vigilância em Saúde. Informe Epidemiológico da Dengue, janeiro a abril de 2008. Disponível em: <http:// portal.saude.gov.br/portal/arquivos/pdf/boletim_dengue_ maio2008.pdf>.

CHALLOUB, S. Cidade Febril: corticos e epidemias na Corte Imperial. São Paulo: Companhia das Letras, 1999.

CHILDS, J. et al. Emerging zoonoses. Emerging Infectious Disease, 4(3): 453-454, 1998.

DE WIT, E. \& FOUCHIER, R. A. Emerging influenza. Journal of Clinical Virology, 41(1): 1-6, 2008.

DOWDLE, W. R. Pandemic influenza: confronting a re-emergent threat - the 1976 experience. The Journal of Infectious Disease, 176(Suppl 1): S69-72, 1997.

FIGUEIREDO, L. T. Emergent arboviruses in Brazil. Revista da Sociedade Brasileira de Medicina Tropical, 40(2): 224-229, 2007.

MCLAUGHLIN-DRUBIN, M. E. \& MUNGER, K. Viruses associated with human cancer. Biochimica et Biophysica Acta, 1.782(3): 127-150, 2008.

MCWILLIAM, J. O. Some account of the yellow fever epidemic by which Brazil was invaded in the latter part of the year 1849. Medical Times, 2: 450, 1851 . 
VAN DER HOEK, L. Human coronaviruses: what do they cause? Antiviral Therapy, 12(4 Pt B): 651-658, 2007.

WALDMAN, E. A. Usos da vigilância e da monitorização em saúde pública. Informe Epidemiológico do SUS, 7(3): 7-26, 1998. 


\section{Sugestões DE Leituras}

GARRETT, L. The Coming Plague: newly emerging diseases in a world out of balance. Londres: Penguin Books, 1995.

Talvez um dos melhores livros sobre doenças emergentes dirigido ao público geral. Laurie Garrett é uma jornalista americana com formação em biologia. Escrito em 1995, ainda é atual. Altamente recomendado. Existe uma edição em português: GARRETT, L. A Próxima Peste: novas doenças em desequilíbrio. São Paulo: Nova Fronteira, 1995.

LUNA, E. J. A. A emergência das doenças emergentes e as doenças infecciosas emergentes e reemergentes no Brasil. Revista Brasileira de Epidemiologia, 5(3): 229-243, 2002.

Um excelente artigo, ainda que curto. Objetivo, ressalta o essencial e mostra como o problema afeta o Brasil.

BARATA BARRADAS, R. de C. O desafio das doenças emergentes e a revalorização da epidemiologia descritiva. Revista Saúde Pública, 31(5): 531-537, 1997.

Interessante por discutir a revalorização da epidemiologia para entender o problema das doenças emergentes.

SCHATZMAYR, H. G. Viroses emergentes e re-emergentes. Cadernos de Saúde Pública, 17(Supl): 209-213, 2001.

Quase um editorial, mas uma excelente introdução ao assunto. Aliás, faz parte de um suplemento da revista que vale a pena ser lido na sua totalidade. 
FIGUEIREDO, L. T. Emergent arboviruses in Brazil. Revista da Sociedade Brasileira de Medicina Tropical, 40(2): 224-229, 2007.

Faz um resumo bastante didático das arboviroses no Brasil. Leitura obrigatória.

\section{Sites de Interesse}

Promed - Conferência eletrônica sobre doenças infecciosas emergentes de humanos, animais e plantas. Em inglês, com versões em português, espanhol, chinês e japonês. Tem o apoio da International Society for Infectious Diseases. Disponível em: $<$ www.promedmail.org $>$.

Emerging Infectious Diseases - Revista eletrônica sobre doenças infecciosas emergentes, editada pelo Centers for Disease Control and Prevention dos Estados Unidos. Acesso gratuito. Disponível em: <http://www.cdc.gov/ncidod/eid>.

Communicable Disease Surveillance and Response - Centro de vigilância epidemiológica da Organização Mundial da Saúde. Publica um boletim semanal, além de alertar sobre surtos em qualquer parte do mundo. Disponível em: < hwww.who.int/ disease-outbreak-news>.

Emerging Infections Network (EIN) - Sistema de vigilância sentinela da Infectious Diseases Society of America. Disponível em: <www.idsociety.org/EIN/TOC.htm>.

Foodborne Pathogenic Microorganisms and Natural Toxins Handbook The Bad Bug Book - Um manual sobre infeccooes transmitidas por alimentos. Traz também informaģöes sobre ocorrências recentes. Mantido pelo Center for Food Safety \& Applied Nutrition do U.S. Food \& Drug Administration, mais conhecido como FDA, o órgão de controle de medicamentos e alimentos dos Estados Unidos. Disponível em: < http://vm.cfsan.fda.gov/ mow/intro.html>. 


\section{GLOSSÁrio}

Aedes aegypti-Mosquito culicídeo, vetor da dengue e da febre amarela urbana. De hábitos diurnos, é extremamente adaptado aos ambientes urbanos. A fêmea é hematófaga e se alimenta exclusivamente de sangue humano.

Arbovírus - Vírus transmitidos por artrópodes. Freqüentemente, os artrópodes são também reservatórios.

Artrópode - Filo de animais invertebrados, que se caracteriza pela presença de corpo segmentado, membros locomotores articulados em número par e exoesqueleto quitinoso. Os crustáceos, insetos, diplópodes, quilópodes e aracnídeos são as principais classes componentes. Os artrópodes são freqüentes vetores de doenças infecciosas, particularmente os insetos e aracnídeos (carrapatos).

Carioteca - Membrana que separa o núcleo (contendo material genético) do citoplasma da célula. Algumas células, como a das bactérias, por exemplo, não têm carioteca. $\mathrm{O}$ material genético fica disperso pela célula.

Contaminação - Presença de microrganismo no ambiente ou em objetos (não em organismos vivos).

Ebola e Marburg - São dois vírus da família Filoviridae, inexistentes no Brasil, responsáveis por sucessivas epidemias de febre hemorrágica na África Central e Austral (Uganda, Gabão, Sudão, República Democrática do Congo, Angola etc.). De elevada 
letalidade, são vírus de morcegos, mas que afetam primatas não humanos e humanos. As epidemias são de difícil controle, não existindo droga ou vacina eficaz.

Endemia/endêmico - Doença ou infecção de ocorrência comum num determinado local, região ou país.

Epidemia/epidêmico - Doença ou infecção que ocorre em número acima do usual para uma determinada área e época.

Infecção - Presença de agente infeccioso num organismo, detectado em sítio normalmente estéril. Infecção não implica doença.

Infestação - Presença de agentes infecciosos ou artrópodes, seja externamente ao organismo (por exemplo, infestação por piolho), seja no ambiente (por exemplo, infestação pelo Aedes aegypti).

Lassa, febre de - Cidade do interior da Nigéria, deu o nome ao vírus e à doença por ele causada. O vírus da febre de Lassa pertence à família Arenaviridae e determina uma febre hemorrágica altamente letal. Identificada em 1976, a febre de Lassa já teve diversos casos importados na Europa e América do Norte. Inexiste vacina, mas os pacientes apresentam boa resposta ao tratamento com ribavirina.

Pandemia/pandêmico - Epidemia que acomete diversos continentes.

Parenteral - Que se faz por outra via que não a digestiva ('para' + 'enteral') ou respiratória. Infecção parenteral é a que se dá através de injeções, transfusões ou transplante de órgãos.

Peste bubônica - Doença bacteriana, causada pela Yersinia pestis, possivelmente originária da Ásia Central. Na natureza, se encontra em roedores silvestres, mas pode afetar roedores urbanos e determinar epidemias extensas com alta letalidade. 
Ao longo da história humana, se conhecem três pandemias: uma iniciada no século V, outra no século XIV e a terceira em 1899. O Brasil foi afetado durante esta última.

Reservatório - Qualquer ser humano, animal, artrópode, planta, solo, matéria (água, por exemplo) ou uma combinação deles, no qual normalmente vive e se multiplica um agente infeccioso, que depende desse meio para sua sobrevivência, reproduzindo-se de modo tal que pode ser transmitido a um hospedeiro susceptível.

Robovírus - Vírus transmitidos por roedores, geralmente por via indireta (pelas fezes e/ou urina).

Síndrome respiratória aguda grave - Doença respiratória mais conhecida pela sigla SARS, de etiologia viral. Causou uma epidemia em 2003, com epicentro na China e que se disseminou para Singapura, Vietnã e Canadá, além de casos importados em diferentes países da Europa, Ásia e América do Norte. Não se verificaram casos no Brasil. Causada por um coronavírus de morcegos, desapareceu após ter causado pouco mais de oitocentos casos humanos.

Transmissão - Transferência de um agente etiológico animado de uma fonte primária de infecção para um novo hospedeiro. Pode ocorrer de forma direta ou indireta.

Vetor-Ser vivo que transmite uma infecção. Os microrganismos podem se multiplicar no vetor ou mesmo necessitar deste para uma fase do seu desenvolvimento, como no caso do vírus da febre amarela.

Viremia - Presença do vírus na circulação sangüínea.

Virose-Doença ou infecção causada por um vírus (ver adiante).

Virulência - Grau de patogenicidade de um agente infeccioso. 
Vírus - Cada um de um grupo de agentes infecciosos diminutos (de $10 \mathrm{~nm}$ a $250 \mathrm{~nm}$ de diâmetro), caracterizados pela falta de metabolismo independente e pela habilidade de se replicar somente no interior de células vivas hospedeiras. São compostos por uma bainha protéica que circunda uma molécula de ácido nucléico (ADN ou ARN).

Zoonose - Infecção ou doença infecciosa transmissível, sob condições naturais, de humanos a animais. Uma zoonose pode se adaptar a humanos a ponto de ser transmitida de pessoa a pessoa. 


Formato: $12,5 \times 18 \mathrm{~cm}$

Tipologia: Letter Gothic e Garamond Papel: Off Set $75 \mathrm{~g} / \mathrm{m}^{2}$ (miolo)

Cartão Supremo $250 \mathrm{~g} / \mathrm{m}^{2}$ (capa)

Fotolitos: Engenho e Arte Editoração Gráfica Ltda. (capa)

CTP, impressão e acabamento: Imprinta Express Ltda.

Rio de Janeiro, setembro de 2008

Não encontrando nossos títulos em livrarias, contactar a EDITORA FIOCRUZ:

Av. Brasil, 4036 - térreo - sala 112 - Manguinhos

21040-361 - Rio de Janeiro - RJ

Tel.: (21) 3882-9039 e 3882-9041

Telefax: (21) 3882-9006

http://www.fiocruz.br/editora

e-mail: editora@fiocruz.br 
